\title{
Fen Bilgisi Öğretmenlerinin Epistemolojik İnançlarının Çeşitli Değişkenlere Göre Değerlendirilmesi*
}

\section{An Evaluation of Science Teachers' Epistemological Beliefs in terms of Several Variables}

\author{
Aysel MURAT** Hilmi ERTEN***
}

Makalenin geliş tarihi: 27.02.2018

Kabul tarihi: 29.05.2018

\section{$\ddot{O} z$}

$\mathrm{Bu}$ çalışmanın amacı fen bilgisi öğretmenlerinin epistemolojik inançlarının cinsiyet, mesleki kıdem ve mezun olunan okul türüne göre incelenmesidir. Tarama modelinin kullanıldığı çalışmaya, Elazığ il ve ilçe merkezinde görev yapmakta olan 200 fen bilgisi öğretmeni katılmıştır. Veriler, Schommer (1998) tarafından geliştirilen ve Karhan (2007) tarafindan Türkçeye çevrilen "Epistemolojik İnançlar Ölçeği” ile toplanmıştır. Ölçek beşli likert tipindedir. Ölçek maddeleri kesinlikle katılmıyorumdan tamamen katılıyoruma doğru derecelendirilmiştir. Ölçek üç alt boyuttan oluşmaktadır. Ölçeğin geneli için hesaplanan Alpha katsayısı .84 olarak bulunmuştur. Ölçeğin üç alt faktörü için hesaplanan Alpha katsayıları sırasıyla .79, .81, ve .76'dır. Verilerin çözümlenmesinde bağımsız gruplar $t$ testi, tek yönlü varyans analizi, Levene testi, Mann Whitney U ve Kruskal Wallis H testleri kullanılmıştır. Araştırma sonucunda, epistemolojik inançlar incelendiğinde, fen bilgisi öğretmenlerinin "bilginin kaynağı uzmandır ve öğrenme yetenek işidir” boyutunda gelişmiş epistemolojik inanca sahip oldukları, "öğrenme çabaya bağlı değildir" boyutunda güçlü bir inanç taşımadıkları, "bilgi tek ve kesindir” boyutunda ise gelişmemiş inanca sahip oldukları tespit edilmiştir. Araştırmada, epistemolojik inançların bazı boyutlarında cinsiyet değişkenine göre kadın öğretmenlerin lehine bulgular ortaya çıkmıştır. Epistemolojik inançların kıdeme göre bazı boyutlarında, ögretmenlerin düşük kıdemlerde gelişmiş olan inançlarının kıdemleri arttıkça gelişmemiş inançlara doğru dönüştüğü görülmüştür. Fen bilgisi öğretmenlerinin epistemolojik inançları arasında mezun olunan kurum değişkenine göre anlamlı farklılıklar ortaya çıkmıştır.

Anahtar Kelimeler: Epistemolojik İnanç, Bilgi, Fen Bilgisi Öğretmeni

\begin{abstract}
The purpose of this study, epistemological beliefs of science teachers were examined in terms of gender, teaching experience and type of institution graduated from. Survey method was used in the study and totally 200 science teachers working in Elazı $\breve{g}$ city and provinces were included in the study. Data were obtained by using "Epistemological Beliefs Scale” developed by Schommer (1998) and adapted into Turkish by Karhan (2007). The scale is a five-point likert style scale. The items are ranged from "strongly disagree" to "totally agree". The scale includes three subscales. Cronbach alpha reliability coefficient of the overall scale was measured to be .84 .

\footnotetext{
*Bu çalışma danışmanlığı Hilmi ERTEN tarafindan yürütülen doktora tezinden üretilmiştir.

**Dr., Frrat Üniversitesi Eğitim Fakültesi. ayselmurat23@gmail.com

*** Dr. Öğr. Üyesi Frrat Üniversitesi Eğitim Fakültesi, Matematik ve Fen Bilimleri Eğitimi Bölümü, Fen Bilgisi Eğitimi Anabilim Dalı / Elazığ. herten@firat.edu.tr
} 
Cronbach Alpha reliability coefficients of the subscales were measured to be $.79, .81$, and .76 respectively. Independent groups t test, One Way ANOVA, Levene test, Mann Whitney U and Kruskal Wallis H tests were used to analyze the data. It was found that science teachers have developed epistemological beliefs in "expert is a source of knowledge and learning is a talent" dimension of epistemological beliefs; have weak beliefs in "learning does not depend on effort" dimension; and they have backward beliefs in "knowledge is unique and certain" dimension of epistemological beliefs. In the study, in some dimensions of epistemological beliefs resulted in favor of female teachers on the basis of gender variable. In some dimensions of epistemological beliefs; it was seen that teachers' developed (sophisticated) beliefs at lower teaching experiences were evolved to less developed (naïve) beliefs when their teaching experiences were increased. It is found that some significant differences have been found among science teachers beliefs according to the variable of the institution graduated from.

Key Words: Epistemological belief, knowledge, science teacher

\section{GIRISŞ}

Bilginin kendisi ve elde edilmesi, öğrenmenin gerçekleşmesi ve nasıl gerçekleştiği öğretim açısından önemlidir. Bireylerin başarılarının, motivasyonlarının artmasını, başarıya ve öğrenmeye olumlu tutumlar sergilemelerini, öğrenmelerinde çaba ve zaman harcamalarını sağlayan birçok bireysel özellik mevcuttur. Bu özelliklerden biri epistemolojik inançlardır. Epistemoloji, ele aldığ konular ve çözmeye çalıştığı sorunlar açısından felsefenin ilk ortaya çıktığı zamandan itibaren yapılan çalışmalarla önemli bir konuma erişmiştir (Baç,2011). Yunanca episteme ve lagos kelimelerinin bileşiminden oluşan epistemoloji kavramında yer alan lagos açıklama, gerekçe, mantık, söz, bilim; episteme bilgi anlamına gelmektedir (Baç, 2011). Genel bir tanımla epistemoloji; bilginin ne olduğunu, bilginin doğasını, kaynağını, sınırlarını sorgulayan felsefenin bir alanıdır (Deryakulu, 2004). Epistemoloji bilginin kavramsal bileşenlerini irdeler (Baç, 2011).

Bireylerin algılamalarını, anlamlandırmalarını ve bunlara yönelik tavrını oluşturan kabullenmelerine inanç denir (Deryakulu, 2004). Alınan bütün kesin yargıların ardında sahip olunan inançlar yatmaktadır ( Hofer ve Pintrich, 1997). Sahip olunan inançlar, oluşturulan tepkileri etkiler (Brown ve Cooney, 1982). Epistemolojik inanç, bireyin bilginin ne olduğu, bilme ve öğrenmenin nasıl gerçekleştiği ile ilgili özel inançları olarak tanımlanmaktadır (Deryakulu, 2004a, s. 259; Hofer ve Pintrich, 1997, s. 88). Epistemolojik inançlar “bilgi nasıl kazanılır?", "bilginin kesinlik derecesi nedir?”, "bilgi için sınırları ve kriterler nelerdir?", "bilgi, öğrencinin dışında gerçekleşen ve disiplin alanlarının otorite figürleri tarafından öğrenciye yüklenmesi sonucu kazanılan bir şey midir yoksa disiplin alanlarının ışığında etkileşim ile mi elde edilen bir şeydir?” şeklindeki soruların cevaplarına ilişkin bireysel görüşleri yansıtmaktadır. Bireylerin bu sorulara ilişkin görüşleri düşünme özellikleri, becerileri sahip oldukları epistemolojik inançlarıyla doğrudan ilgilidir (Paul ve Elder, 2002: Tezci ve Uysal, 2004, s.158). 
Epistemolojik inançlar, alan yazında, her zaman bilgi ve bilginin doğası ile ilgili bir inançlar sistemi olarak tanımlanmaktadır (Schommer-Aikins, 2002; Hofer ve Pintrich, 1997; Duell ve Schommer-Aikins, 2001; Chan, 2008). Bilginin kaynağı, doğruluğu, bilginin ölçütleri, bilginin sınırları ve öğrenme konularındaki inançlar epistemolojik inançlar kapsamında yer almaktadır. Bir öğretmenin sahip olduğu bilginin doğası ile ilgili inançları onun öğretme biçimini, öğrencileri değerlendirmede kullandığı ölçütleri, ders planlarını ve genel olarak okul programının organizasyonunu etkilemektedir (Duell ve Schommer-Aikins, 2001; Kıssack, 2002). 1960'lardan buyana yapılan araştırmalar, epistemolojik inançlar ve öğrenme arasında çok sayıda bağlantının olduğuna işaret etmektedir.

Epistemolojik inançlar ile ilgili yapılan çalışmaların temelinde William Perry’ nin 1970 yılında erkek üniversite öğrencileri üzerinde görüşme yolu ile gerçekleştirdiği, bilgiye olan inançların üniversite yılları içinde değişip değişmediğini ortaya koyan araştırması vardır (Buehl ve Alexander 2001, s.385). Perry'nin bu çalışmasında erkek üniversite öğrencilerinin üniversiteye ilk başladıklarında bilginin kesin, bilginin basit ve bilginin kaynağının bir uzman olduğu inancı hâkimken yıllar geçtikçe bilginin kesin olmadığı, bilginin karmaşık ve bilginin kaynağının akıl olduğuna inancın hâkim olduğunu vurgulamıştır (Kıralp, Şahin ve Dinçyürek 2008, s.98).

Epistemolojik inançlar üzerine yapılan araştırmalar ve bu alana olan ilgi, 1990'ların sonlarında bu yana artmaktadır (Chan, 2008: s. 258). Yapılan araştırmalar epistemolojik anlayışların öğrenme üzerine önemli etkileri olduğunu göstermiştir. Örneğin, Hofer (2008, s.3), tarafından, bilginin doğası hakkındaki inançların, strateji kullanımını, anlamayı, bilişsel işlem süreçlerini ve kavramsal değiş̧imi etkileyebileceği ileri sürülmüştür. Eğitim konusunda gerçekleştirilecek reformlara engel oluşturan etmenlerin temelinde, büyük oranda öğretmenlerin değişime ne derece eğilimli olduklarını belirleyen inançları yatmaktadır. $\mathrm{Bu}$ nedenle, öğretmen eğitimindeki programların düzenlenmesinde ve uygulanmasında "öğretmen adaylarının epistemolojik inançlarının bilinmesi” önemli görülmektedir (Öngen, 2003). Epistemolojik inançlar, öğretmenlerin sınıf içindeki eğitim ve öğretim etkinliklerini (hangi öğretme yöntem ve tekniklerinin kullanılacağı, sınıfın nasıl yönetileceği, öğrenmede neye odaklanılacağı gibi) büyük oranda etkilemektedir.

Arredondo ve Terrance (1996) eğitimde reform uygulamalarının başarısında öğretmenlerin epistemolojik inançlarının önemli ölçüde etkili olduğunu vurgularken, Beck, Czerniak ve Lumpe (2000), eğitimde reform hareketlerinde öğretmenleri kilit noktada görmekte, öğretmenlerin pedagojik inançlarının eğitimde reform uygulamalarında arzulanan değişim için çok önemli olduğunu ileri sürmektedirler (Akt. Karhan, 2007: s. 95). Kuşkusuz bu durum, eğitim ve öğretimle ilgili diğer tüm uygulamaların da kapsamına alınabilir. Diğer yandan, bir öğretim programının başarısı öğretmenlerin bu programı uygulama başarılarına bağlıdır (Fer, 2011: s. 4).

Öğretmenlerin bilgi, düşünme, inanç, kuram ve bunun gibi epistemolojileri üzerine taranan literatür, bunların, öğretmenlerin ne yaptıkları ve neden yaptıklarını önemli bir şekilde şekillendirdiğini göstermektedir (Clark ve Peterson, 1986; Akt. Ekiz, 2006: s. 93). Bu çalışma alanlarından özellikle ögretmenlerin epistemolojik inançları üzerinde bir odaklaşmanın olduğu göze çarpmaktadır. Yapılan 
çalışmalarda, eğitim süreçlerini anlamak ve geliştirebilmek için, öğretmenlerin inançları, uygulama ve tutumlarının dikkate alınması gerektiği vurgulanmaktadır (Ekonomik İşbirliği ve Kalkınma Örgütü (OECD), 2009).

Öğretme ve öğrenmede epistemolojik inançların önemi açıktır. Bu düşünce araştırma literatüründe de destek bulmuştur. Bu yüzden epistemolojik inançlar gelecekteki öğretmen eğitimi analizlerinde daha önemli olacağı muhtemeldir. Öğretmenlerin sadece biliş ötesi aktivitelerini ve nasıl öğretileceği ile ilgili öğrenme süreçlerini anlamada değil, aynı zamanda gelecekteki öğretmenlerin seçimi için kullanılacak stratejilerin anlaşılmasında da epistemolojik inançlar önemli olacaktır (Chan ve Elliott, 2004). Diğer yandan bilgi ile ilgili inançların öğrenme ortamındaki diğer faktörlerle nasıl bir ilişki içinde olduğunu anlamak, öğrencilerin sınıfta başarılarını ve karşılaştıkları zorlukları anlamaya yardım edebilir ve eğitimi geliştirmek için bir yol sunabilir. Bu inançlar öğrencilerin akademik başarıları için daha avantajlı ise, eğitim deneyimleri bu inançları geliştirmek için tasarlanabilir (Buehl, 2008).

Araştırma bulguları, gerek yurt dışında gerekse yurt içinde son yıllarda epistemolojik inançlar üzerinde araştırmacıların giderek artan bir ilgisinin olduğunu göstermektedir. Bununla beraber, uluslararası literatürde epistemolojik inançlar üzerine birçok çalışmanın yapılmış olduğu, ancak ülkemizde halen yeterli düzeyde çalışmanın yapılmamış olduğu, yapılan çalışmalar arasında ise bir ilişkiyi inceleyen çalışmaların az olduğu (Kaleci ve Yazıcı, 2012) söylenebilir.

İlgili literatür incelendiğinde, 1970’lerden bu yana epistemolojik inançların gelişim düzeyleri ile kültür (Chan ve Elliot, 2004), cinsiyet, yaş, aile ve eğitim düzeyi (Schommer, 1990; 1993; 1998), öğrenme (Tanrıverdi, 2012), akademik başarı (Schommer, 1990; 1993), alan (Schommer ve Walker, 1997), zekâ düzeyi (Schommer ve Dunnel, 1997), okula yönelik tutum (Schommer ve Walker, 1997), öğretim stratejileri (Hashweh, 1996), ders çalışma stratejileri (Deryakulu, 2004), problem çözme stratejileri (Öngen, 2003), uygulama (Savaşçı- Açıkalın, 2009), öğretme-öğrenme anlayışları (Aypay, 2011) gibi bir çok farklı değişkenlerle ilişkileri incelenmiştir. Nitekim yapılan araştırmalar, eğitimle ilgili değişim çabalarının uygulamaya geçirilmesinde anahtar rolün öğretmenlerde olduğunu ve öğretmenlerin içselleştirmediği hiçbir değişim çabasının sınıf ortamına yansımadığını (Fullan, 2001) göstermektedir. Bütün bu görüşler ve çalışmalar 1şığında öğrenme ve öğretmenin temel dinamiklerinden biri olarak görülen öğretmenlerin epistemolojik inançları da dikkat çeken bir durum olarak belirmektedir. Epistemolojik inançların öğrenme sürecini etkileyen bir unsur olmasından ötürü, öğretmenlerin hizmetiçi dönemdeki durumları üzerinde çalışılmasının literatüre önemli bir katkı sağlayacağı düşünülmüştür. Bu düşünce doğrultusunda, bu çalışma ile fen bilgisi öğretmenlerinin epistemolojik inançları belirlenmeye çalışılmıştır.

Araştırmanın Amacı

$\mathrm{Bu}$ araştırmada fen bilgisi öğretmenlerinin benimsedikleri epistemolojik inançlarının çeşitli değişkenler (cinsiyet, mesleki kıdem ve mezun olunan eğitim kurumu) açısından incelenmesi amaçlanmıştır. Buna göre aşağıdaki alt amaçlar belirlenmiştir.

1. Fen bilgisi öğretmenlerinin epistemolojik inançlarının düzeyi nedir? 
2. Fen bilgisi öğretmenlerinin epistemolojik inançları cinsiyetlerine göre anlamlı farklılık göstermekte midir?

3. Fen bilgisi öğretmenlerinin epistemolojik inançları mesleki kıdemlerine göre anlamlı farklılık göstermekte midir?

4. Fen bilgisi öğretmenlerinin epistemolojik inançları mezun olunan eğitim kurumuna göre anlamlı farkl11ık göstermekte midir?

\section{YÖNTEM}

$\mathrm{Bu}$ araştırma tarama modeline göre desenlenmiştir. Tarama modeli var olan duruma müdahale etmeden olduğu gibi betimlemeyi amaçlamaktadır. Tarama modeli araştırmalarda evrenin tamamından ya da belli bir gruptan veriler toplanabilir. Gruptan elde edilen bilgiler çalışmanın verilerini oluşturur. Tarama modeli kullanılarak yapılan araştırmalarda durumun nedeninden çok değişkenler arasındaki ilişkinin belirlenmesi söz konusudur (Neuman, 2008; Karasar, 2012).

Çalışma Grubu

Çalışma evrenini 2016-2017 eğitim öğretim yılında Elazığ il ve ilçe merkezinde görev yapan Fen Bilgisi öğretmenleri oluşturmuştur. Örneklem seçiminde küme örnekleme yönteminden oransız küme örnekleme türü seçilmiştir. Bu yönteme uygun olarak ölçeği doldurmayı kabul eden 200 fen bilgisi öğretmeni çalışmanın örneklemini oluşturmaktadır (Tablo 1).

Tablo 1

Çalışma Grubuna ait kişisel bilgiler

\begin{tabular}{|c|c|c|c|}
\hline & & $\mathrm{N}$ & $\%$ \\
\hline \multirow{3}{*}{ Cinsiyet } & Kadın & 95 & 47.5 \\
\hline & Erkek & 105 & 52.5 \\
\hline & Toplam & 200 & 100 \\
\hline \multirow{8}{*}{ Kıdem } & $1-5 \mathrm{y} 11$ & 28 & 14 \\
\hline & $6-10 \mathrm{y} 1 \mathrm{l}$ & 42 & 21 \\
\hline & $11-15$ y1l & 22 & 11 \\
\hline & $16-20$ y1l & 32 & 16 \\
\hline & $21-25$ y1l & 46 & 23 \\
\hline & $26-30$ y1l & 9 & 4.5 \\
\hline & 31 y1l ve üstü & 21 & 10.5 \\
\hline & Toplam & 200 & 100 \\
\hline \multirow{5}{*}{$\begin{array}{c}\text { Mezun } \\
\text { Olunan } \\
\text { Eğitim } \\
\text { Kurumu }\end{array}$} & AÖF-Eğitim Ön Lisans & 7 & 3.5 \\
\hline & Eğitim Enstitüsü & 23 & 11.5 \\
\hline & Eğitim Fakültesi & 114 & 57 \\
\hline & Diğer & 56 & 28 \\
\hline & Toplam & 200 & 100 \\
\hline
\end{tabular}

AÖF: Açı Öğretim Fakültesi

\section{Veri Toplama Aracı ve Verilerin Analizi}

Schommer (1998)'in kendinden önceki araştırmacıların, özellikle de Perry'nin görüşme yöntemi ile yürüttüğü çalışmalarından yola çıkarak geliştirdiği Epistemolojik İnanç Ölçeği (EİÖ), 27'si ters kodlamayı gerektiren toplam 63 önermeden oluşan 5'li likert tipi bir ölçektir. Ölçekten alınabilecek 
en düşük puan 1, en yüksek puan 5'tir. Ölçek maddelerine verilebilecek yanttlardan "Kesinlikle katılmıyorum" ifadesinin karşı1lı̆̆ "1" dir. Cevaplayıcıların ölçek maddesine katılma derecesi arttıkça verilen puan da artmaktadır. Deneklerden, ölçek maddesine kesinlikle katılıyorlarsa " 5 " i işaretlemeleri istenmiştir. Ölçekteki önermeler yüzeysel (naive) inançlara sahip bireylerin katılacağı ifadelerdir (Schommer, 1990, s. 499). Bundan dolayı ölçekten alınan yüksek puanlar yüzeysel inançlara, düşük puanlar ise sofistike inançlara sahip olunduğunu göstermektedir.

Özgün ölçeğin test-tekrar-test güvenirliği “.74” ve ölçeği oluşturan maddelerin madde toplam korelasyon katsayıları “.63” ile “.85” arasında değişmektedir (Schommer, 1993, 407). Karhan (2007) tarafından “Epistemolojik İnanç Ölçeği'nin üniversite öğrencileri ve yetişkinler için kullanılan formunun (Schommer, 1998) Türkçeye çevrilmesi dolayısıyla önce dilsel eşdeğerlik çalışması yürütülmüş, ölçeğin Türkçe formunun dilsel ve kültürel eşdeğerliği ve yeterli geçerlik ve güvenirliğe sahip olduğu görüldükten sonra ölçek "öğretmen” deneklere yönelik olacak şekilde uyarlanmıştır. Bu amaçla 8 maddede değişiklik yapılmıştır.

Karhan (2007) tarafindan yapılan açımlayıcı faktör analizi çalışmaları sonucunda ölçeğin üç faktörlü bir yapıya sahip olduğu belirlenmiştir. Birinci faktör "bilginin kaynağı uzmandır ve öğrenme yetenek işidir" şeklinde adlandırılmıştır. Bu faktörde 17 (16 ters ve 1 olumlu ifade) madde yer almıştır. İkinci faktör "öğrenme çabaya bağlı değildir" şeklinde adlandırılmıştır. Bu boyutta 11 madde yer almıştır. Üçüncü boyut ise "bilgi tek ve kesindir" şeklinde adlandırılmıştır ve bu boyutta 10 madde yer almıştır. Güvenirlik alpha değeri, toplam 17 maddeden oluşan birinci faktör için “,72”, ikinci faktör için “,68”, üçüncü faktör için “,67” ve tüm ölçek için yine “,67”dir. EİÖ’ nün bu araştırma kapsamında güvenirliğinin hesaplanması için Cronbach Alfa güvenirlik katsayısı yeniden hesaplanmıştır. Ölçekte yer alan birinci faktör için güvenirlik katsayısı .82, ikinci faktör için .81, üçüncü faktör için .76 dır. Tüm ölçeğe ait Cronbach Alfa katsayısı .80 olarak hesaplanmıştır. Bu sonuçlar Epistemolojik İnanç Ölçeği’nin güvenirliğinin yüksek olduğunu göstergesi olarak kabul edilebilir.

Ölçekte düşük ortalama gelişmiş (sofistike) inançları, yüksek ortalama yüzeysel (naif ya da gelişmemiş) inançları ifade etmektedir. Bir başka deyişle düşük ortalama öğrenme yeteneğinin gelişebileceğine, kişinin kendisinin bilgiyi oluşturarak bilgi üretebileceğine, öğrenmenin çaba ve uğraş sonucu gerçekleşeceğine, gerçeklerin zamanla değişebileceğine olan inancı ifade etmektedir. Yüksek ortalama ise tam tersi öğrenme yeteneğinin kalıtsal olduğuna, dolayısıyla zeki öğrencilerin pek de çaba harcamadan ve çabuk kavradıklarına, diğerlerinin ise kısıtlı öğrenme yeteneklerinden dolayı zor problemleri ne kadar uğraşsalar da çözemeyeceklerine, böyle kişiler için çabanın öğrenme ile sonuçlanmayacağına, gerçeklerin kesin ve değişmezliğine olan inancı ifade etmektedir.

Değerlendirme yapılırken 1'e yaklaşan (1 ile 2,49 arası) ortalamalar gelişmiş (sofistike) inançların, 5'e yaklaşan (3,50 ile 5 arası) ortalamalar ise yüzeysel (gelişmemiş) inançların göstergesi olarak kabul edilmişlerdir. Tam ortada, 2,50 ile 3,49 arasında kalan ortalamaların ise bireylerin ölçek maddelerine katılıp katılmadıkları konusunda güçlü bir inanç taşımadıklarının göstergesi olarak kabul edilmiştir. Araştırmanın amaçları doğrultusunda elde edilen veriler SPSS 22 paket program kullanılarak 
analiz edilmiştir. Verilerin analizinde bağımsız gruplar t testi, tek yönlü varyans analizi, levene testi, MWU ve KWH testleri kullanılmıştır.

\section{BULGULAR}

Araştırmanın bu bölümünde, fen bilgisi öğretmenlerinin epistemolojik inançlarının çeşitli değişkenlere göre karşılaştırılmasına yer verilmiştir. Araştırmanın "Fen Bilgisi öğretmenlerinin epistemolojik inançlarının düzeyi nedir?” alt problemine ilişkin bulgular epistemolojik inançların üç alt boyutunda incelenmiş̧tir. Bunlar: (1) "Bilginin kaynağı uzmandır ve öğrenme yetenek işidir", (2) "Öğrenme çabaya bağlı değildir”, (3) "Bilgi tek ve kesindir” alt boyutlarıdır.

Öğretmenlerin epistemolojik inançları, bu alt boyutlara ilişkin olarak, aritmetik ortalama ve standart sapma değerlerine dayalı olarak sunulmuştur (Tablo 2, Tablo 3, Tablo 4).

\section{Bilginin kaynăğ uzmandır ve öğgrenme yetenek işidir alt boyutuna ilişkin öğretmenlerin görüsşleri}

Öğretmenlerin epistemolojik inançlarının "bilginin kaynağı uzmandır ve öğrenme yetenek işidir" alt boyutuna yönelik görüşlerine ilişkin betimsel bulgular Tablo 2'de sunulmuştur

Tablo 2

Epistemolojik İnançların, "Bilginin Kaynağı Uzmandır ve Öğrenme Yetenek İşidir” Boyutuna İlişkin Öğretmenlerin Görüşleri

\begin{tabular}{|c|c|c|c|c|}
\hline Mad. & Iffadeler & $\mathbf{N}$ & $\bar{X}$ & $\mathbf{S}$ \\
\hline 26 & Ölüm dışında hiçbir şey kesin değildir. & 200 & 2.25 & 1.13 \\
\hline 32 & $\begin{array}{l}\text { Bir ders kitabını anlamanın iyi bir yolu, kitaptaki bilgileri kendinize göre yeniden } \\
\text { düzenlemenizdir }\end{array}$ & 200 & 2.45 & 1.01 \\
\hline 11 & $\begin{array}{l}\text { Otoritelerin fikir birliğine varamadıkları konular üzerinde düşünmenin zihnimi } \\
\text { açtığını düşünüyorum. }\end{array}$ & 200 & 2.45 & .90 \\
\hline 10 & $\begin{array}{l}\text { Bir kitabı yeniden okuyacak zamanı bulursam, ikinci okuyuşta daha çok şey } \\
\text { anlarım. }\end{array}$ & 200 & 2.14 & .90 \\
\hline 18 & $\begin{array}{l}\text { Ayrıntıları unuttuğu halde, yine de okuduğu metinden yeni fikirler çıkarabiliyorsa, } \\
\text { ben o kişinin zeki olduğunu düşünürüm. }\end{array}$ & 200 & 2.30 & .88 \\
\hline 13 & $\begin{array}{l}\text { Bir cümlenin hangi durumda kullanıldığını bilmiyorsanız, size çok az şey ifade } \\
\text { eder. }\end{array}$ & 200 & 2.03 & .97 \\
\hline 23 & Konuya aşına iseniz, ders kitabındaki bilginin doğruluğunu değerlendirmelisiniz. & 200 & 2.24 & .89 \\
\hline 31 & $\begin{array}{l}\text { Zor kavramları, genellikle dikkati dağıtan dış etmenlerden kurtulduğunuzda ve } \\
\text { gerçekten konsantre olduğunuzda anlayabilirsiniz. }\end{array}$ & 200 & 2.28 & .98 \\
\hline 5 & $\begin{array}{l}\text { Okuduğum kitabın bölümleri arasında, hatta değişik derslerdeki bilgiler arasında } \\
\text { bağlantı kurmak için elimden geleni yaparım. }\end{array}$ & 200 & 1.98 & .79 \\
\hline 9 & Bilimsel çalışmanın en önemli yanı yaratıcı özgün düşünmedir. & 200 & 1.91 & .87 \\
\hline 12 & Herkes nasıl öğreneceğini öğrenmek zorundadır. & 200 & 2.13 & .97 \\
\hline 14 & İyi bir öğrenci olmak, genellikle bilgileri ezberlemeyi gerektirir. & 200 & 2.20 & 1.13 \\
\hline 6 & $\begin{array}{l}\text { Çok başarılı insanlar, öğrenme yeteneklerini nasıl geliştireceklerini } \\
\text { keşfetmişlerdir. }\end{array}$ & 200 & 2.00 & .94 \\
\hline 24 & Çoğu zaman, uzmanların önerileri bile sorgulanmalıdır. & 200 & 2.04 & .88 \\
\hline 20 & Bir kimse bir şeyi kısa bir süre içinde anlayamıyorsa, çabalamaya devam etmelidir. & 200 & 1.84 & .77 \\
\hline 15 & $\begin{array}{l}\text { Akıllı olmak, soruların cevaplarını bilmek değil, cevapların nasıl bulunacağını } \\
\text { bilmektir. }\end{array}$ & 200 & 1.89 & .88 \\
\hline \multirow[t]{2}{*}{36} & Bugünün gerçekleri yarının masalları olabilir. & 200 & 2.18 & .94 \\
\hline & Bilginin Kaynağı Uzmandır ve Öğrenme Yetenek İşidir Alt Boyutu & 200 & 2.13 & .48 \\
\hline
\end{tabular}


Epistemolojik inançların "bilginin kaynağı uzmandır ve öğrenme yetenek işidir” boyutuna ilişkin olarak Tablo 2' deki ortalamalar incelendiğinde, katılım düzeyinin en yüksek olduğu maddeler "Bir ders kitabını anlamanın iyi bir yolu, kitaptaki bilgileri kendinize göre yeniden düzenlemenizdir.” ( $\bar{X}$ 32=2.45), "Otoritelerin fikir birliğine varamadıkları konular üzerinde düşünmenin zihnimi açtığını düşünüyorum.” ( $\left.\overline{\mathrm{X}}_{11}=2.45\right)$ ve "Ayrıntıları unuttuğu halde, yine de okuduğu metinden yeni fikirler çıkarabiliyorsa, ben o kişinin zeki olduğunu düşünürüm.” ( $\bar{X} 18=2.30)$ maddeleridir. Katılım düzeyinin en düşük olduğu maddeler ise "Bir kimse bir şeyi kısa bir süre içinde anlayamıyorsa, çabalamaya devam etmelidir." ( $\overline{\mathrm{X}} 20=1.84)$, “Akıllı olmak, soruların cevaplarını bilmek değil, cevapların nasıl bulunacağını bilmektir." ( $\overline{\mathrm{X}} 15=1.89$ ) ve "Okuduğum kitabın bölümleri arasında, hatta değişik derslerdeki bilgiler arasında bağlantı kurmak için elimden geleni yaparım.” ( $\overline{\mathrm{X}} 5=1.98$ ) maddeleridir.

Araştırma bulgularına göre katılımcı öğretmenlerin epistemolojik inançların "bilginin kaynağı uzmandır ve öğrenme yetenek işidir" boyutunda yer alan 17 önermeye de "katılmıyorum" düzeyinde cevap verdikleri belirlenmiştir. Öğretmenlerin bu boyut için genel aritmetik ortalama puanları $(\bar{X}=$ 2.13) ortaya çıkmıştır. Bu bulguya göre, fen bilgisi öğretmenleri, bilginin kaynağının uzmanlar olduğu ve öğrenme yeteneğinin doğuştan gelen bir özellik olduğu yönündeki inançlara katılmadıklarını göstermiştir. Yani, bu bulgu öğretmenlerin "bilginin kaynağı uzmandır ve öğrenme yetenek işidir” boyutunda gelişmiş (sofistike) epistemolojik inançlara sahip olduklarının bir göstergesi olarak kabul edilebilir. Buna göre, öğretmenlerin bilginin kişilerin kendileri tarafından üretilebileceğine, kendi bilgilerini oluşturabileceklerine, uzmanların bilgilerinin sorgulanabileceğine, öğrenme yeteneğinin doğuştan gelen bir özellik olmadığına, sonradan gelişebileceğine inandıklarını göstermiştir.

\section{2. Ö̆̆renme çabaya bağlı değildir alt boyutuna ilişkin öğretmenlerin görüşleri}

Öğretmenlerin epistemolojik inançlarının “öğrenme çabaya bağlı değildir” boyutuna yönelik görüşlerine ilişkin betimsel bulgular Tablo 3'de sunulmuştur. Epistemolojik inançların “öğrenme çabaya bağlı değildir" boyutuna ilişkin ortalamalar incelendiğinde, katılım düzeyinin en yüksek olduğu maddeler "kimi insanlar iyi öğrenenler olarak doğmuşlardır, kimileri ise öğrenme konusunda sınırlı yeteneğe sahiptirler" ( $\bar{X} 25=3.27$ ), "Kimi zaman, anlamasanız da öğretmenin verdiği yanıtları kabul etmek zorunda kalırsınız" ( $\bar{X}$ 21=3.20) ve "Fen derslerinin en iyi tarafı, pek çok problemin yalnızca bir doğru cevabının olmasıdır" ( $\overline{\mathrm{X}} 35=3.17$ ) maddeleridir. 
Tablo 3

Epistemolojik İnançların Öğrenme Çabaya Bağlı Değildir Boyutuna İlişkin Öğretmenlerin Görüşleri

\begin{tabular}{|c|c|c|c|c|}
\hline Mad. & İfadeler & $\mathbf{N}$ & $\bar{X}$ & $\mathbf{S}$ \\
\hline 25 & $\begin{array}{l}\text { Kimi insanlar iyi öğrenenler olarak doğmuşlardır, kimileri ise öğrenme konusunda } \\
\text { sınırlı yeteneğe sahiptirler. }\end{array}$ & 200 & 3.27 & 1.09 \\
\hline 35 & $\begin{array}{l}\text { Fen derslerinin en iyi tarafı, pek çok problemin yalnızca bir doğru cevabının } \\
\text { olmasıdır. }\end{array}$ & 200 & 3.17 & 1.13 \\
\hline 21 & $\begin{array}{l}\text { Kimi zaman, anlamasanız da öğretmenin verdiği yanıtları kabul etmek zorunda } \\
\text { kalırsınız. }\end{array}$ & 200 & 3.20 & .91 \\
\hline 27 & $\begin{array}{l}\text { Gerçekten zeki olan öğrenciler, okulda başarılı olmak için çok çalışmak zorunda } \\
\text { değildirler. }\end{array}$ & 200 & 3.01 & 1.12 \\
\hline 22 & $\begin{array}{l}\text { Belirsizlikten uzak, kesin bir yanıta ulaşma olasılığı olmayan problemler üzerinde } \\
\text { çalışmak zaman kaybıdır. }\end{array}$ & 200 & 2.85 & .97 \\
\hline 28 & $\begin{array}{l}\text { Zor bir problem üzerinde uzun bir süre sıkı çalışmak, sadece gerçekten zeki } \\
\text { öğrencilerde olumlu sonuç verir. }\end{array}$ & 200 & 2.79 & 1.12 \\
\hline 37 & "Kendi kendine öğren/ Kendin yap" türü kitaplar pek de işe yaramaz. & 200 & 2.70 & 1.08 \\
\hline 29 & $\begin{array}{l}\text { Bir kişi bir sorunu anlamak için çok fazla uğraşırsa, büyük bir olasılıkla sonunda } \\
\text { kafası karışacaktır. }\end{array}$ & 200 & 2.74 & 1.02 \\
\hline 30 & Bir kitaptan edinebileceğiniz bilgilerin hemen tümünü ilk okuyuşta edinirsiniz. & 200 & 2.70 & .99 \\
\hline 38 & $\begin{array}{l}\text { Okuduğunuz kitabındaki yeni fikirlerle, o konu hakkında önceden bildiklerinizi } \\
\text { birleştirmeye çalışırsanız kafanız karışacaktır. }\end{array}$ & 200 & 2.71 & 1.10 \\
\hline \multirow[t]{2}{*}{33} & $\begin{array}{l}\text { Okulda "vasat" olan öğrenciler hayatlarının geri kalan kısmında da "vasat" olarak } \\
\text { kalırlar. }\end{array}$ & 200 & 2.31 & 1.10 \\
\hline & Öğrenme Çabaya Bağlı Değildir Alt Boyutu & 200 & 2.86 & .62 \\
\hline
\end{tabular}

Katılım düzeyinin en düşük olduğu maddeler ise, "Okulda "vasat” olan öğrenciler hayatlarının geri kalan kısmında da “vasat” olarak kalırlar.” ( $\bar{X} 33=2.31)$, ““'Kendi kendine öğren/ Kendin yap” türü kitaplar pek de işe yaramaz." ( $\bar{X} 37=2.70$ ) ve "Bir kitaptan edinebileceğiniz bilgilerin hemen tümünü ilk okuyuşta edinirsiniz.” ( $\overline{\mathrm{X}} 30=2.70$ ) maddeleridir. Araştırma bulgularına göre, fen bilgisi öğretmenlerin epistemolojik inançların "öğrenme çabaya bağlı değildir” boyutunda yer alan 11 önermenin 10'nuna “ kısmen katılıyorum” ve birine "katılmıyorum" düzeyinde cevap verdikleri tespit edilmiştir. Epistemolojik inançların "öğrenme çabaya bağlı değildir” boyutuna ilişkin olarak genel aritmetik ortalama puan ise $\bar{X}=2.86$ olarak belirlenmiştir. Bu bulguya göre öğretmenlerin güçlü bir inanç taşımadıkları, anlaşılmaktadır. Genel ortalamanın yüksek olmadığı ve aritmetik ortalamalar sofistike inançlara doğru bir kayma gösterdiğinden, öğretmenlerin öğrenmenin çabaya bağlı olup olmadığı konusunda, gelişmemiş epistemolojik inançlardan gelişmiş epistemolojik inançlara doğru bir geçiş aşamasında oldukları söylenebilir. Bu durum, öğretmenlerin hâlâ, önceki öğretim programlarının geliştirilmesinde temel alınan davranış̧̧ı anlayışın etkisinde olduklarının, uygulamaya konulan öğretim programının temel aldığı yapılandırmacı epistemolojiyi henüz tam olarak benimsemediklerinin bir göstergesi olarak kabul edilebilir. 


\section{Bilgi tek ve kesindir alt boyutuna ilişkin öğretmenlerin görüşleri}

Öğretmenlerin epistemolojik inançlarının "bilgi tek ve kesindir” boyutuna yönelik görüşlerine ilişkin betimsel bulgular Tablo 4'te sunulmuştur.

Tablo 4

Epistemolojik İnançların Bilgi Tek ve Kesindir Boyutuna İlişkin Öğretmenlerin Görüşleri

\begin{tabular}{clccc}
\hline Mad. & \multicolumn{1}{c}{ İfadeler } & $\mathbf{N}$ & $\bar{X}$ & $\mathbf{S}$ \\
\hline 2 & Başarılı öğrenciler çabuk kavrarlar . & 200 & 3.89 & 1.06 \\
\hline 7 & Bilimsel çalışmanın en önemli yanı hatasız ölçüm ve dikkatli çalışmadır. & 200 & 3.73 & .93 \\
\hline \multirow{2}{*}{34} & $\begin{array}{l}\text { Derslerini titizlikle planlayan ve planına sadık kalan öğretmenleri gerçekten takdir } \\
\text { ederim. }\end{array}$ & 200 & 4.00 & 1.04 \\
\hline \multirow{2}{*}{$\begin{array}{l}\text { İyi bir öğretmenin görevi, öğrencilerinin doğru yanıta giden yoldan } \\
\text { uzaklaşmamalarını sağlamaktır. }\end{array}$} & 200 & 3.81 & .93 \\
\hline 19 & Ders çalışırken kesin olan doğruları ararım. & 200 & 3.37 & .92 \\
\hline 8 & Bilim adamları eninde sonunda gerçeklere ulaşırlar & 200 & 3.50 & .92 \\
\hline 1 & Bir insanın okuldan ne kadar yararlandı̆̆ı daha çok öğretmenin kalitesine bağlıdır. & 200 & 3.52 & 1.12 \\
\hline 4 & $\begin{array}{l}\text { Bilim adamları yeterince sıkı çalışırlarsa hemen her şeyin altında yatan gerçeği } \\
\text { bulabilirler. }\end{array}$ & 200 & 3.30 & 1.01 \\
\hline 17 & Gerçek değişmezdir. & 200 & 3.11 & 1.28 \\
\hline 16 & Pek çok sözcüğün açık ve net tek bir anlamı vardır. & 200 & 3.12 & 1.00 \\
\hline & Bilgi Tek ve Kesindir Boyutu & $\mathbf{2 0 0}$ & $\mathbf{3 . 5 3}$ & $\mathbf{. 5 9}$ \\
\hline
\end{tabular}

Epistemolojik inançların "bilgi tek ve kesindir" boyutuna ilişkin olarak Tablo 4'daki bulgular incelendiğinde, katılım düzeyinin en yüksek olduğu maddeler "Derslerini titizlikle planlayan ve planına sadık kalan öğretmenleri gerçekten takdir ederim.” ( $\bar{X} 34=4.00)$, "Başarılı öğrenciler çabuk kavrarlar ." ( $\overline{\mathrm{X}} 2=3.89)$ ve “İyi bir öğretmenin görevi, öğrencilerinin doğru yanıta giden yoldan uzaklaşmamalarını sağlamaktır. " ( $\overline{\mathrm{X}} 3=3.81)$ maddeleridir. Katılım düzeyinin en düşük olduğu maddeler ise "Gerçek değişmezdir. " ( $\bar{X} 17=3.11)$, "Pek çok sözcügün açık ve net tek bir anlamı vardır. " ( $\overline{\mathrm{X}} 16=3.12)$ ve "Bilim adamları yeterince sıkı çalışırlarsa hemen her şeyin altında yatan gerçeği bulabilirler. "( $\overline{\mathrm{X}} 4=3.30)$ maddeleridir.

Araştırma bulgularına göre, katılımcı öğretmenler epistemolojik inançların "bilgi tek ve kesindir" boyutundaki 10 maddeden yedisine "kat1liyorum", dördüne "kısmen kat1lıyorum" düzeyinde görüş belirttikleri görülmüştür. Genel ortalama puanın $(\overline{\mathrm{X}}=3.53)$ katılıyorum düzeyinde olduğu görülmektedir. Genel ortalama puan, gelişmemiş inanç olarak kabul edilen sınıra (3.50-5.00) çok yakın bir değer almıştır. Bu bulgular, araştırmaya katılan öğretmenlerin, bilgi tek ve kesindir boyutunda güçlü bir inanç taşımadıklarının, geleneksel inanca daha yakın durduklarının bir göstergesi olarak kabul edilebilir.

\section{Epistemolojik inançların çeşitli değişkenler açısından incelenmesi.}

Fen bilgisi öğretmenlerinin epistemolojik inançlarının cinsiyet değişkenine göre farklılaşıp farklılaşmadığına ilişkin yapılan t-testi sonuçları Tablo 5' te sunulmuştur. 
Tablo 5

Öğretmenlerin Epistemolojik İnançlarının Cinsiyet Değişkenine Göre t-Testi Sonuçları

\begin{tabular}{|c|c|c|c|c|c|c|c|c|c|c|}
\hline & \multirow{2}{*}{ Alt Ölçek } & \multirow{2}{*}{ Cinsiyet } & \multirow{2}{*}{$\mathbf{n}$} & \multirow{2}{*}{$\bar{X}$} & \multirow{2}{*}{ Ss } & \multicolumn{2}{|c|}{ Levene Testi } & \multirow{2}{*}{ sd } & \multirow{2}{*}{$\mathbf{T}$} & \multirow{2}{*}{$\mathbf{p}$} \\
\hline & & & & & & $\mathbf{F}$ & $\mathbf{p}$ & & & \\
\hline \multirow{8}{*}{ 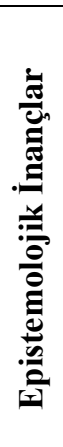 } & \multirow{2}{*}{$\begin{array}{l}\text { Bilginin Kaynağı Uzmandır } \\
\text { ve Öğrenme Yetenek İşidir }\end{array}$} & Kadın & 95 & 2.10 & .46 & \multirow[b]{2}{*}{.460} & \multirow[b]{2}{*}{.498} & \multirow[b]{2}{*}{198} & \multirow{2}{*}{1.022} & \multirow[b]{2}{*}{.306} \\
\hline & & Erkek & 105 & 2.17 & .50 & & & & & \\
\hline & \multirow{2}{*}{$\begin{array}{l}\text { Öğrenme Çabaya Bağlı } \\
\text { Değildir }\end{array}$} & Kadın & 95 & 2.71 & .56 & \multirow{2}{*}{1.196} & \multirow[b]{2}{*}{.275} & \multirow{2}{*}{198} & \multirow{2}{*}{$\begin{array}{c}- \\
3.138\end{array}$} & \multirow{2}{*}{$.002 *$} \\
\hline & & Erkek & 105 & 2.98 & .65 & & & & & \\
\hline & \multirow[b]{2}{*}{ Bilgi Tek ve Kesindir } & Kadın & 95 & 3.34 & .54 & \multirow[b]{2}{*}{.001} & \multirow[b]{2}{*}{.972} & \multirow[b]{2}{*}{198} & \multirow{2}{*}{4.678} & \multirow[b]{2}{*}{$.000 *$} \\
\hline & & Erkek & 105 & 3.71 & .56 & & & & & \\
\hline & \multirow[b]{2}{*}{$\begin{array}{l}\text { Epistemolojik İnanç } \\
\text { (Ölçeğin Tümü) }\end{array}$} & Kadın & 95 & 2.60 & .31 & \multirow[b]{2}{*}{.016} & \multirow[b]{2}{*}{.899} & \multirow[b]{2}{*}{198} & \multirow[b]{2}{*}{$\begin{array}{c}- \\
4.428\end{array}$} & \multirow[b]{2}{*}{$.000 *$} \\
\hline & & Erkek & 105 & 2.81 & .34 & & & & & \\
\hline
\end{tabular}

$* \mathrm{P}<0.05$

Tablo 5'te yer alan cinsiyet değişkenine göre bağımsız gruplar "t" testi sonuçları incelendiğinde, öğretmenlerin epistemolojik inançlarının "bilginin kaynağı uzmandır ve öğrenme yetenek işidir" alt boyutuna [t(198)=-1.022; $\mathrm{p}=.306]$ ilişkin görüşleri arasında kadın ve erkek öğretmenler arasında anlamlı bir farklılık görülmemiştir. Kadın $(\bar{X}=2.10)$ ve erkek $(\bar{X}=2.17)$ öğretmenler, ortalama puanlarıyla katılmıyorum düzeyinde görüş bildirerek gelişmiş (sofistike) inançlara sahip oldukları görülmüştür. Ölçekten alınan düşük puanlar gelişmiş (sofistike) inançların bir göstergesi olarak kabul edildiğinden öğretmenlerin epistemolojik inançların bilginin kaynağı uzmandır ve öğrenme yetenek işidir alt boyutuyla ilgili inançlarının gelişmiş olduğu söylenebilir. Başka bir ifadeyle kadın ve erkek öğretmenler, bilginin herkes tarafından üretilebileceğine ve öğrenmenin bir yetenek işi olduğuna, zamanla geliştirilebileceğine inandıkları tespit edilmiştir.

Tablo 5'e göre, öğretmenlerin "öğrenme çabaya bağlı değildir” alt boyutuna $[\mathrm{t}(198)=-3.138$; $\mathrm{p}=0.02$ ] ilişkin görüşleri arasında kadın öğretmenlerin lehine anlamlı düzeyde farklılık olduğu görülmektedir. Kadın öğretmenlerin görüşlerine ilişkin ortalama puan $(\bar{X}=2.71)$, erkek öğretmenlere ait ortalama puandan $(\bar{X}=2.98)$ daha düşüktür. Buna göre kadın öğretmenlerin epistemolojik inançların öğrenme çabaya bağlı değildir alt boyutuyla ilgili inançlarının erkek öğretmenlere göre daha olgunlaşmış olduğu söylenebilir. Katılımcı öğretmenlerin epistemolojik inançlarının "bilgi tek ve kesindir" alt boyutundaki görüşleri arasında $[\mathrm{t}(198)=-4.678 ; \mathrm{p}=0.00]$ ise, kadın öğretmenlerin lehine anlamlı düzeyde farklı1ık olduğu ortaya çıkmıştır. Kadın öğretmenlerin görüşlerine ilişkin ortalama puan ( $\bar{X}=3.34)$, erkek öğretmenlere ait ortalama puandan $(\bar{X}=3.71)$ daha düşüktür. Buna göre kadın öğretmenlerin epistemolojik inançların bilgi tek ve kesindir, alt boyutuyla ilgili inançlarının erkek öğretmenlere göre daha ileri olduğu söylenebilir. Kadın öğretmenler güçlü bir inanç taşımıyorken erkek öğretmenler gelişmemiş (naif) bir inanç taşıdıkları görülmüştür. Fen bilgisi öğretmenlerinin epistemolojik inanç ölçeği genelindeki görüşleri arasında $[\mathrm{t}(198)=-4.428 ; \mathrm{p}=0.00]$ kadın öğretmenlerin lehine anlamlı düzeyde farklılık olduğu ortaya çıkmıştır. Kadın öğretmenlerin görüşlerine ilişkin ortalama puan $(\bar{X}=2.60)$, erkek öğretmenlere ait ortalama puandan $(\bar{X}=2.81)$ daha düşüktür. Buna 
göre kadın öğretmenlerin kişinin kendisinin bilgiyi oluşturabileceğine, öğrenmenin çaba sonucu gelişebileceğine ve gerçeğin zamanla değişebileceğine olan inançları erkek öğretmenlerin inançlarına göre daha güçlü olabileceği görülmüştür.

\section{Mesleki kıdem değişkenine göre öğretmenlerin epistemolojik inançlarına ilişkin bulgular}

Katılımcı öğretmenlerin epistemolojik inançlarının "bilginin kaynağı uzmandır ve öğrenme yetenek işidir", "öğrenme çabaya bağlı değildir” ve "bilgi tek ve kesindir" alt boyutlarına ilişkin inançlarının kıdem değişkenine göre varyans analiz sonuçları Tablo 6' da sunulmuştur.

Tablo 6

Öğretmenlerin Epistemolojik İnançlarının Kıdem Değişkenine Göre Varyans Analiz Sonuçları

\begin{tabular}{|c|c|c|c|c|c|c|c|c|c|c|c|c|}
\hline $\begin{array}{c}\text { Alt } \\
\text { Ölç. }\end{array}$ & & Kıdem & $\mathbf{N}$ & $\bar{X}$ & ss & $\begin{array}{l}\text { Vary. } \\
\text { Kay. }\end{array}$ & $\begin{array}{l}\text { Kar. } \\
\text { Top. }\end{array}$ & Sd & $\begin{array}{l}\text { Kar. } \\
\text { Ort. }\end{array}$ & $\mathbf{F}$ & $\mathbf{p}$ & Fark \\
\hline \multirow{9}{*}{ 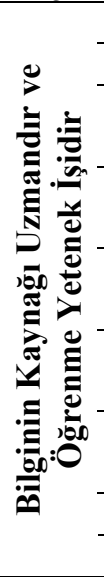 } & 1 & $1-5 \mathrm{y} 1 \mathrm{l}$ & 28 & 1.89 & .41 & \multirow{3}{*}{$\begin{array}{l}\text { Gruplar } \\
\text { Aras1 }\end{array}$} & \multirow{3}{*}{3.186} & \multirow{3}{*}{6} & \multirow{3}{*}{.531} & \multirow{7}{*}{2.379} & \multirow{7}{*}{$.031 *$} & \multirow{7}{*}{$\begin{array}{c}1-3,5,6,7 \\
2-7\end{array}$} \\
\hline & 2 & 6-10 y1l & 42 & 2.08 & .57 & & & & & & & \\
\hline & 3 & $\begin{array}{l}11-15 \\
\mathrm{y} 11\end{array}$ & 22 & 2.20 & .42 & & & & & & & \\
\hline & 4 & $\begin{array}{l}16-20 \\
\text { y1l }\end{array}$ & 32 & 2.12 & .43 & \multirow{4}{*}{$\begin{array}{l}\text { Gruplar } \\
\text { İçi }\end{array}$} & \multirow{4}{*}{43.066} & \multirow{4}{*}{193} & \multirow{4}{*}{.223} & & & \\
\hline & 5 & $\begin{array}{l}21-25 \\
\text { y1l }\end{array}$ & 46 & 2.18 & .49 & & & & & & & \\
\hline & 6 & $\begin{array}{l}26-30 \\
\text { y1l }\end{array}$ & 9 & 2.34 & .45 & & & & & & & \\
\hline & 7 & $\begin{array}{l}31 \text { yıl } \\
\text { ve üstü }\end{array}$ & 21 & 2.34 & .37 & & & & & & & \\
\hline & & plam & 200 & 2.13 & .48 & Toplam & 46.252 & 199 & & & & \\
\hline & & vene: & 1.073 & $\mathrm{P}=.380$ & & & & & & & & \\
\hline \multirow{9}{*}{ 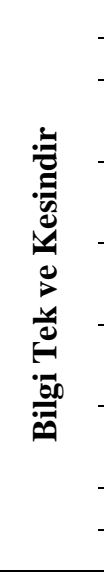 } & 1 & $1-5 \mathrm{yll}$ & 28 & 3.15 & .48 & \multirow{3}{*}{$\begin{array}{l}\text { Gruplar } \\
\text { Aras1 }\end{array}$} & \multirow{3}{*}{10.697} & \multirow{3}{*}{6} & \multirow{3}{*}{1.783} & \multirow{7}{*}{5.976} & \multirow{7}{*}{$.000 *$} & \multirow{7}{*}{$\begin{array}{c}1- \\
3,4,5,6,7 \\
2-3,4,5,7\end{array}$} \\
\hline & 2 & 6-10 y1l & 42 & 3.30 & .51 & & & & & & & \\
\hline & 3 & $\begin{array}{l}11-15 \\
\text { y1l }\end{array}$ & 22 & 3.60 & .56 & & & & & & & \\
\hline & 4 & $\begin{array}{l}16-20 \\
\text { y1l }\end{array}$ & 32 & 3.74 & .62 & $\begin{array}{l}\text { Gruplar } \\
\text { İçi }\end{array}$ & \multirow{4}{*}{57.574} & \multirow{4}{*}{193} & \multirow{4}{*}{.298} & & & \\
\hline & 5 & $\begin{array}{l}21-25 \\
\text { y1l }\end{array}$ & 46 & 3.63 & .56 & & & & & & & \\
\hline & 6 & $\begin{array}{l}26-30 \\
\text { y1l }\end{array}$ & 9 & 3.68 & .66 & & & & & & & \\
\hline & 7 & $\begin{array}{l}31 \text { yıl } \\
\text { ve üstü }\end{array}$ & 21 & 3.85 & .43 & & & & & & & \\
\hline & & plam: & 200 & 3.53 & .58 & Toplam & 68.271 & 199 & & & & \\
\hline & & vene: & 1.416 & $\mathrm{P}=.210$ & & & & & & & & \\
\hline \multirow{9}{*}{ 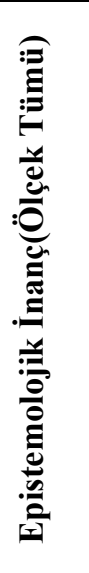 } & 1 & $1-5 \mathrm{y} 11$ & 28 & 2.44 & .29 & \multirow{3}{*}{$\begin{array}{l}\text { Gruplar } \\
\text { Aras1 }\end{array}$} & \multirow{3}{*}{4.640} & \multirow{3}{*}{6} & \multirow{3}{*}{.773} & \multirow{7}{*}{7.791} & & \\
\hline & 2 & $6-10 \mathrm{y} 11$ & 42 & 2.57 & .34 & & & & & & & \\
\hline & 3 & $\begin{array}{l}11-15 \\
\text { yll }\end{array}$ & 22 & 2.82 & .29 & & & & & & & \\
\hline & 4 & $\begin{array}{l}16-20 \\
\text { y1l }\end{array}$ & 32 & 2.82 & .35 & $\begin{array}{l}\text { Gruplar } \\
\text { İçi }\end{array}$ & & & & & & $\begin{array}{l}1- \\
34567\end{array}$ \\
\hline & 5 & $\begin{array}{l}21-25 \\
\text { y1l }\end{array}$ & 46 & 2.75 & .32 & & & & & & $.000^{*}$ & $\begin{array}{l}2- \\
3,4,5,6,7\end{array}$ \\
\hline & 6 & $\begin{array}{l}26-30 \\
\text { y1l }\end{array}$ & 9 & 2.88 & .23 & & 19.155 & 193 & .099 & & & \\
\hline & 7 & $\begin{array}{l}31 \text { yıl } \\
\text { ve üstü }\end{array}$ & 21 & 2.91 & .20 & & & & & & & \\
\hline & & plam & 200 & 2.71 & .34 & Toplam & 23.794 & 199 & & & & \\
\hline & & vene & 1.657 & $\mathrm{P}=.134$ & & *p<.05 & & & & & & \\
\hline
\end{tabular}


Tablo 6'daki bulgulara göre, katılımcı öğretmenlerin epistemolojik inançlarının "bilginin kaynağı uzmandır ve öğrenme yetenek işidir” alt boyutuna ilişkin görüşleri arasında kıdem değişkenine göre anlamlı bir düzeyde farklılık olduğu belirlenmiştir $[\mathrm{F}(6-193)=2.379, \mathrm{p}<0,05]$. LSD farkl11ık testi sonuçlarına göre, farklılıkların 1-5 yılına ait kıdemdeki ( $\overline{\mathrm{X}}=1.89)$ öğretmenlerle daha yüksek kıdeme sahip öğretmenlerin görüşleri arasında olduğu anlaşılmaktadır. 1-5 yıl kıdem süresine sahip öğretmenlerin gelişmiş epistemolojik inanca sahip oldukları görülmektedir.

Araştırma bulgularına göre, en düşük aritmetik ortalama puanın 1-5 yıl ( $\bar{X}=1.89)$, en yüksek aritmetik ortalama puanın ise 26-30 yıl ve 30 yıl üstü ( $\bar{X}=2.34)$ kıdeme sahip öğretmenlerin görüşlerine ait olduğu anlaşılmıştır. Bu sonuçlara göre, 1-5 y1l kıdeminde bulunan öğretmenlerin, epistemolojik inançların "bilginin kaynağı uzmandır ve öğrenme yetenek işidir" alt boyutunda diğer öğretmenlere göre inançlarının daha gelişmiş olduğu, diğer öğretmenlerin ise bilginin kaynağı uzmandır ve öğrenmenin yetenek işi olduğu konusunda kıdemleri yükseldikçe genel olarak inançlarının azaldığı görülmektedir.

Öğretmenlerin, epistemolojik inançların "bilgi tek ve kesindir" alt boyutu ile ilgili görüşleri arasında kıdem değişkenine göre anlamlı bir farklılık olduğu tespit edilmiştir $[F(6-193)=5.976, p<0,05]$. LSD farklı1ık testi sonuçlarına göre bu farklılı̆̆ın, 1-5 yıl kıdemindeki ( $\bar{X}=3.15)$ ögretmenlerin lehine olmak üzere, $16-20$ y1l $(\overline{\mathrm{X}}=3.74), 21-25$ y1l $(\overline{\mathrm{X}}=3.63)$ ve 31 y1l üstü $(\overline{\mathrm{X}}=3.85)$ kıdemlerdeki öğretmenlerin görüşleri arasında olduğu anlaşılmıştır. Benzer şekilde, 6- 10 yıl kıdemdeki $(\bar{X}=3.30)$ öğretmenlerin lehine olmak üzere, 16-20 y1l $(\bar{X}=3.74)$ ve 31 y1l üstü $(\bar{X}=3.85)$ kıdemlerdeki öğretmenlerin görüşleri arasında da anlamlı bir farklılık ortaya çıkmıştır. Araştırma bulgularına göre, en düşük aritmetik ortalama puanın 1-5 yıl ( $\bar{X}=3.15)$, en yüksek aritmetik ortalama puanın ise 30 yıl ve üstü ( $\bar{X}=3.85)$ kıdeme sahip öğretmenlerin görüşlerine ait olduğu anlaşılmıştır. Bu sonuçlara göre, 1-5 y11 ve 6-10 y1l kıdemi olan öğretmenlerin, epistemolojik inançların "bilgi tek ve kesindir" alt boyutunda diğer öğretmenlere göre inançlarının daha gelişmiş olduğu, diğer öğretmenlerin ise bilginin tek ve kesin olup olmadığı konusunda güçlü bir inanç taşımadıkları, kıdem yükseldikçe genel olarak öğretmenlerin inançlarının zayıfladığı görülmektedir.

Ölçek genelindeki bulgulara göre ise fen bilgisi öğretmenlerinin kıdem değişkenine göre görüşleri arasında istatistiksel olarak anlamlı bir farklılık görülmüştür $[F(6-193)=7.791, p<0,05]$. LSD farklılık testi sonuçlarına göre, farklı1ıkların 1-5 kıdemdeki ( $\bar{X}=2.44)$ öğretmenlerle daha yüksek kıdeme sahip ve 6-10 yıl kıdemdeki ( $\bar{X}=2.54)$ öğretmenlerle daha fazla kıdeme sahip öğretmenlerin görüşleri arasında olduğu anlaşılmaktadır. 1-5 yıl ve 6-10 yıl kıdem süresine sahip öğretmenlerin gelişmiş epistemolojik inanca sahip oldukları görülmektedir. 
Öğretmenlerin öğrenme çabaya bağlı değildir alt ölçeğine ilişkin KWH testi sonuçları Tablo 7'de verilmiştir.

Tablo 7

Öğretmenlerin Öğrenme Çabaya Bağlı Değildir Alt Ölçeğine İlişkin KWH Testi Sonuçları

\begin{tabular}{|c|c|c|c|c|c|c|c|c|}
\hline Alt Ölçek & & Kıdem & $\mathbf{n}$ & Sira Ortalaması & sd & KWH & $\mathbf{p}$ & Fark \\
\hline \multirow{9}{*}{ 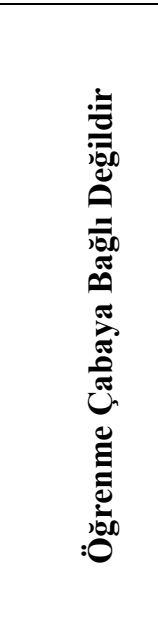 } & 1 & $1-5$ y1l & 28 & 78.61 & \multirow{9}{*}{6} & \multirow{9}{*}{$14.488 *$} & \multirow{9}{*}{.025} & \multirow{9}{*}{$1-3,4,7$} \\
\hline & 2 & $6-10$ yil & 42 & 86.32 & & & & \\
\hline & 3 & $11-15$ y1l & 22 & 122.18 & & & & \\
\hline & 4 & $16-20 \mathrm{y} 1 \mathrm{l}$ & 32 & 117.64 & & & & \\
\hline & 5 & $21-25$ y1l & 46 & 95.55 & & & & \\
\hline & 6 & $26-30$ yil & 9 & 116.28 & & & & \\
\hline & 7 & 31 yıl ve üstü & 21 & 113.29 & & & & \\
\hline & & Toplam & 200 & & & & & \\
\hline & & Levene & 2.751 & $\mathrm{P}=.014$ & & & & \\
\hline
\end{tabular}

Tablo 7'ye göre, öğretmenlerin, “öğrenme çabaya bağlı değildir” boyutu ile ilgili görüşleri arasında kıdem değişkenine göre anlamlı düzeyde bir farklılık olduğu belirlenmiştir [KWH(6)=14.488, $p<.05]$. Bunun üzerine farkın kaynağını bulmak için yapılan MWU testi sonucunda, farklılıkların 1-5 kıdemdeki öğretmenlerin lehine olmak üzere, 1-5 kıdemdeki $(\mathrm{SO}=78.61)$ öğretmenlerle 11-15 yıl $(\mathrm{SO}=122.18), 16-20$ y1l $(\mathrm{SO}=117.64)$ ve 31 y1l üstü $(\mathrm{SO}=113.29)$ k1demdeki öğretmenlerin görüşleri arasında olduğu görülmüştür. 6-10 yıl (SO=86.32) ile 11-15 yıl (SO=122.18) kıdeme sahip öğretmenler arasında 6-10 yıl kıdeme sahip öğretmenler lehine anlamlı fark bulunmuştur. 11-15 yıl (SO=122.18) kıdemdeki öğretmenlerin lehine olmak üzere $16-20$ yıl $(\mathrm{SO}=117.64)$ ve 31 ve üstü yıl $(\mathrm{SO}=113.29)$ kıdeme sahip öğretmenler arasında anlamlı farklılıklar görülmüş̧ür.

\section{Mezun olunan ĕ̆itim kurumu değişkenine göre öğretmenlerin epistemolojik inançlarına ilişkin bulgular}

Fen bilgisi öğretmenlerinin epistemolojik inançlarının "bilginin kaynağı uzmandır ve öğrenme yetenek işidir", "öğrenme çabaya bağlı değildir" ve "bilgi tek ve kesindir" boyutlarına ilişkin inançlarının mezun olunan eğitim kurumu değişkenine göre varyans analiz sonuçları Tablo 8' de sunulmuştur. 
Tablo 8

Fen Bilgisi Öğretmenlerinin Epistemolojik İnanç Alt Ölçeklerine İlişkin KWH Testi Sonuçları

\begin{tabular}{|c|c|c|c|c|c|c|c|c|c|}
\hline Alt Ö & lçek & & MOK & $\mathbf{n}$ & Sira Ort. & sd & KWH & $\mathbf{p}$ & Fark \\
\hline \multirow{6}{*}{ 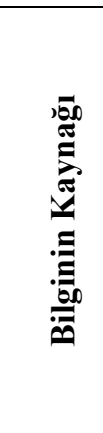 } & \multirow{6}{*}{ 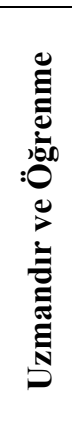 } & 1 & AÖF-Eğitim Ön Lisans & 7 & 120.07 & \multirow{6}{*}{3} & \multirow{6}{*}{$8.597 *$} & \multirow{6}{*}{.035} & \multirow{6}{*}{$\begin{array}{l}3-2 \\
4-2\end{array}$} \\
\hline & & 2 & Eğitim Enstitüsü & 23 & 131.04 & & & & \\
\hline & & 3 & Eğitim Fakültesi & 114 & 94.41 & & & & \\
\hline & & 4 & Diğer & 56 & 97.90 & & & & \\
\hline & & & Toplam & 200 & & & & & \\
\hline & & & Levene & 4.439 & $\mathrm{P}=.005$ & & & & \\
\hline \multirow{6}{*}{ 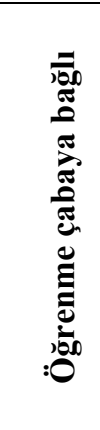 } & \multirow{6}{*}{ 氕 } & 1 & AÖF-Eğitim Ön Lisans & 7 & 128.36 & \multirow{6}{*}{3} & \multirow{6}{*}{6.448} & \multirow{6}{*}{.092} & \multirow{6}{*}{---- } \\
\hline & & 2 & Eğitim Enstitüsü & 23 & 124.07 & & & & \\
\hline & & 3 & Eğitim Fakültesi & 114 & 96.81 & & & & \\
\hline & & 4 & Diğger & 56 & 94.85 & & & & \\
\hline & & & Toplam & 200 & & & & & \\
\hline & & & Levene & 3.468 & $\mathrm{P}=.017$ & & & & \\
\hline & \multirow{6}{*}{ 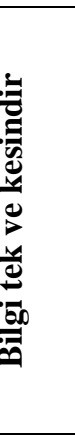 } & 1 & AÖF-Eğitim Ön Lisans & 7 & 121.00 & \multirow{6}{*}{3} & \multirow{6}{*}{$25.272 *$} & \multirow{6}{*}{.000} & \multirow{6}{*}{$\begin{array}{l}3-2 \\
3-4\end{array}$} \\
\hline & & 2 & Eğitim Enstitüsü & 23 & 139.39 & & & & \\
\hline & & 3 & Eğitim Fakültesi & 114 & 83.61 & & & & \\
\hline & & 4 & Diğer & 56 & 116.35 & & & & \\
\hline & & & Toplam & 200 & & & & & \\
\hline & & & Levene & 3.416 & $\mathrm{P}=.018$ & & & & \\
\hline \multirow{6}{*}{ : } & & 1 & AÖF-Eğitim Ön Lisans & 7 & 137.50 & \multirow{6}{*}{3} & \multirow{6}{*}{$19.421 *$} & \multirow{6}{*}{.000} & \multirow{6}{*}{$3-1,2$} \\
\hline & $:$ & 2 & Eğitim Enstitüsü & 23 & 142.93 & & & & \\
\hline & : & 3 & Eğitim Fakültesi & 114 & 89.42 & & & & \\
\hline & 漶 & 4 & Diğer & 56 & 101.00 & & & & \\
\hline & :อַ & & Toplam & 200 & & & & & \\
\hline & & & Levene & 5.161 & $\mathrm{P}=.002$ & & & & \\
\hline
\end{tabular}

Tablo 8'deki bulgulara göre, öğretmenlerin epistemolojik inançlarının "bilginin kaynağ1 uzmandır ve öğrenme yetenek işidir” alt boyutuna ilişkin görüşleri arasında, mezun olunan eğitim kurumu değişkenine göre, anlamlı düzeyde farklılık tespit edilmiştir [KWH(3)= 8.597, p<.05]. Bunun üzerine farkın kaynağını bulmak için yapılan MWU testi sonucuna göre bu farklılığın eğitim fakültesinden mezun öğretmenler ile eğitim enstitüsü mezunu öğretmenler arasında ve diğer 
fakültelerden mezun olan öğretmenler ile eğitim enstitüsünden mezun olan öğretmenler arasında olduğu ortaya çıkmıştır. Eğitim fakültesinden $(\mathrm{SO}=94.41)$ ve diğer fakültelerden $(\mathrm{SO}=97.90)$ mezun öğretmenlerin görüşlerine ilişkin sıra ortalama puanlarının, eğitim enstitüsünden ( $\mathrm{SO}=131.04)$ mezun öğretmenlerin görüşlerine ilişkin sıra ortalama puanlarından daha yüksektir.

Katılımc1 öğretmenlerin Tablo 8'deki bulgulara göre, epistemolojik inançlarının “öğrenme çabaya bağlı değildir" alt boyutuna ilişkin görüşleri arasında, mezun olunan eğitim kurumu değişkenine göre, anlamlı düzeyde farklılık tespit edilmemiştir $[\mathrm{KWH}(3)=6.448, \mathrm{p}>.05]$. Analiz sonuçlarına göre, en düşük sıra ortalama puanın ( $\mathrm{SO}=94.85$ ) ortalama ile diğer fakültelerden mezun öğretmenlere, en yüksek sıra ortalamanın ise $(\mathrm{SO}=128.36)$ ile AÖF-Eğitim Ön Lisanstan mezun olan öğretmenlere ait olduğu tespit edilmiştir. Bu bulgulara göre öğretmenlerin epistemolojik inançlarının "öğrenme çabaya bağlı değildir” alt boyutuyla ilgili puanlarının mezun olunan eğitim kurumuna göre farklılaşmadığı söylenebilir.

Tablo 8'deki bulgulara göre, katılımcı öğretmenlerinin epistemolojik inançlarının "bilgi tek ve kesindir" alt boyutuna ilişkin görüşleri arasında mezun olunan eğitim kurumu değişkenine göre anlamlı bir düzeyde farklılık olduğu belirlenmiştir $[\mathrm{KWH}(3)=25.272$, p<.05]. Bunun üzerine farkın kaynağını bulmak için yapılan MWU testi sonucuna göre bu farklılı̆̆ın eğitim fakültesinden mezun öğretmenler ile eğitim enstitüsü ve diğer fakültelerden mezun öğretmenler arasında olduğu ortaya çıkmıştır. Eğitim fakültesinden mezun öğretmenlerin görüşlerine ilişkin sıra ortalama puanlarının ( $\mathrm{SO}=83.61$ ), eğitim enstitüsünden $(\mathrm{SO}=139.39)$ ve diğer fakültelerden $(\mathrm{SO}=116.35)$ mezun öğretmenlerin görüşlerine ilişkin sıra ortalama puanlarından daha yüksektir.

Tablo 8'deki bulgulara göre, katılımcı öğretmenlerinin epistemolojik inanç ölçeği geneline ilişkin görüşleri arasında mezun olunan eğitim kurumu değişkenine göre anlamlı bir düzeyde farklılık olduğu belirlenmiştir [KWH(3)=19.921, p<.05]. Bunun üzerine farkın kaynağını bulmak için yapılan MWU testi sonucuna göre bu farklılı̆̆ın eğitim fakültesinden mezun öğretmenler ile AÖF-Eğitim ön lisans ve eğitim enstitüsünden mezun öğretmenler arasında olduğu ortaya çıkmıştır. Eğitim fakültesinden mezun öğretmenlerin görüşlerine ilişkin sıra ortalama puanlarının ( $\mathrm{SO}=89.42$ ), AÖFEğitim ön lisans ( $\mathrm{SO}=137.50)$ ve eğitim enstitüsünden ( $\mathrm{SO}=142.93)$ mezun öğretmenlerin görüşlerine ilişkin sıra ortalama puanlarından daha yüksektir. MWU testi sonucunda çıkan diğer bir farklılık ise diğer fakülte mezunu öğretmenler ile eğitim enstitüsü mezunu öğretmenler arasındadır. Diğer fakültelerden mezun olan öğretmenlerin görüşlerine ilişkin sıra ortalama puanları $(\mathrm{SO}=101.00)$, eğitim enstitüsünden ( $\mathrm{SO}=142.93)$ mezun öğretmenlerin görüşlerine ilişkin sıra ortalama puanlarından daha yüksektir. 


\section{TARTIŞMA, SONUÇ VE ÖNERILER}

Araştırmanın alt problemlerine ilişkin ulaşılan sonuçlar gruplandırılarak sunulmuştur.

Araştırma bulgularına göre, fen bilgisi öğretmenlerinin epistemolojik inançlarının "bilginin kaynağı uzmandır ve öğrenme yetenek işidir” boyutundaki önermelere katılmadıkları saptanmıştır. Bu bulgu fen bilgisi öğretmenlerinin bu boyutta gelişmiş epistemolojik inançlara sahip olduklarını göstermektedir. Bu bulgudan hareketle şu sonuca ulaşılabilir: Araştırmaya katılan öğretmenler, bilginin kendileri tarafından üretilebileceğine, kendi bilgilerini inşa edebileceklerine, uzmanların bilgilerinin de sorgulanabileceğine, öğrenme yeteneğinin doğuştan gelen bir özellik olmadığına, sonradan gelişebileceğine yüksek düzeyde inanmaktadırlar.

Araştırmanın bu bulgusu literatürdeki çalışmalar ile benzerlik gösterdiği söylenebilir. BacanlıKurt (2010), ilköğretim öğretmenlerinin bilginin kaynağının uzman ya da kitaplar olduğuna dair inançlarının ve öğrenme yeteneğinin doğuştan gelen bir özellik olduğuna dair inançlarının düşük olduğunu ortaya koymaktadır. Öğretmenlerin öğrenme yeteneğinin gelişebileceğine ve kişinin kendisinin de bilgi üretebileceğine dolayısıyla uzmanların/bilenlerin de sorgulanabileceğine yüksek düzeyde inanmaktadırlar. Özdemir (2013), Epistemolojik inançların öğrenmenin yeteneğe bağlı olduğuna yönelik yapılan görüşmelerde öğretmenlerin \%50'si doğuştan getirilen özelliklerin, yeteneklerin ve zekânın öğrenme üzerinde daha etkili olduğunu söylemiş ve bireylerin her şeyi tam anlamıyla öğrenemeyeceğini ifade etmiştir. İçen (2012) sosyal bilgiler öğretmenlerinin epistemolojik inançlarıyla ilgili araştırmasında öğretmenlerin yeniliğe açık, gelişmiş inançlara sahip olduğunu, kısacası pozitivist felsefi anlayışa yakın olmaktan ziyade, post modernist felsefi anlayışı benimsediklerini bulmuştur. Akyıldız (2014), katılımcı öğretmenlerin epistemolojik inançların "bilginin kaynağı uzmandır ve öğrenme yetenek işidir” boyutundaki önermelere katılmadıkları saptanmıştır. Bu bulgu katılımcı öğretmenlerin bu boyutta gelişmiş (sofistike) epistemolojik inançlara sahip olduklarını göstermektedir

Araştırmada, katılımcı öğretmenler, epistemolojik inançların, "öğrenme çabaya bağlı değildir” boyutuna ilişkin ifadeleri "kısmen katılıyorum" düzeyinde benimsemiş oldukları belirlenmiştir. Buna göre, katılımcı öğretmenlerin epistemolojik inançlarında, öğrenme çabaya bağlı değildir inancından öğrenmenin çabaya bağlı olduğu inancına doğru, bir kayma olduğu sonucu çıkarılabilir. Bu araştırmaya ilişkin elde edilen bulgu alan yazındaki çalışmalarla da paralellik göstermektedir. Özbaş (2013), sınıf öğretmenleriyle yaptığı çalışmasında öğrenme çabaya bağlı değildir boyutunda kısmen katılıyorum düzeyinde oldukları görülmektedir. Bu sonuca göre sınıf öğretmenlerinin, öğrenmenin çabayla gelişebileceği düşüncesine tam olarak inanmadıkları, zihinsel özelliklere dayalı olabileceğinin göstergesi olarak düşünülmektedir. Akyıldız (2014), katılımcı öğretmenler, epistemolojik inançların, “öğrenme çabaya bağlı değildir” boyutuna ilişkin ifadeleri "kısmen katılıyorum” düzeyinde benimsemiş olduklarını belirlemiştir. Bacanlı Kurt (2010)'un araştırmasıyla paralellik göstermekle beraber, Karhan (2007) ve İçen'in (2012) araştırmalarında da öğretmenlerin “Öğrenme çabaya bağlı değildir” 
boyutundan aldıkları puanlar, birinci boyuttaki kadar sofistike olmasa da sofistike uca yakın olarak bulunmuştur. Araştırma sonuçları, öğretmenlerin bu boyutta çok da geleneksel inançlara sahip olmadığını göstermektedir.

Araştırma bulgularına göre katılımcı öğretmenlerin epistemolojik inançların "bilgi tek ve kesindir" boyutuna ilişkin önermeleri "katılıyorum" düzeyinde benimsedikleri anlaşılmaktadır. $\mathrm{Bu}$ bulgudan hareketle, araştırmaya katılan öğretmenlerin, epistemolojik inançlarının, bilgi tek ve kesindir boyutunda güçlü bir inanç taşımadıkları, geleneksel pozitivist inanca daha yakın durdukları sonucuna varılmıştır. Bu bulgular bu boyuta ilişkin Karhan(2007), Bacanlı Kurt(2010) ve Akyıldız (2014) tarafindan yapılan araştırmaların sonuçlarıyla da benzerdir. Chan ve Elliott (2000), Hong Kong öğretmenlik programında okuyan öğrenciler üzerinde yaptığı araştırmada, Hong Kong'lu öğrencilerin bilginin kesin ve mutlak olduğuna ve uzmanların her şeyi bildiklerine inandıklarını, dolayısıyla onların bilgi ve düşüncelerini sorgulamadan doğru olarak kabul etmeye eğilimli olduklarını saptanmıştır. Benzer çalışmalar incelendiğinde, Eroğlu ve Güven (2006) üniversite öğrencilerinin epistemolojik inançlarını inceleyen araştırmasında, tek bir doğrunun var olduğuna dair inanç puanlarını, diğer boyutlara oranla daha yüksek bulmuştur. Öğretmen adaylarının da geleneksel anlayışa sahip olması, lisans eğitiminde bilginin doğasına ilişkin yeni keşiflere açık, öğrenciyi merkeze alan, öğrencisiyle birlikte öğrenen, yapılandırmacı öğretimi gerçek anlamda uygulayabilen öğretmenler yetiştirmenin önemini bir kez daha göstermektedir. Bu bulgular aynı zamanda öğretmen adaylarının epistemolojik inançları üzerinde yapılan araştırmaların (Aksan ve Sözer, 2007; Deryakulu, ve Bıkmaz, 2003; Deryakulu ve Büyüköztürk, 2005; Erdem, Y1lmaz ve Akkoyunlu, 2008; Eroğlu ve Güven, 2006) sonuçlarıyla büyük ölçüde tutarlıdır.

Fen bilgisi öğretmenlerinin bu boyutta yüksek puana sahip olması, ulaşılabilecek farklı bilgileri kabul etmeyip, kitaplardan ve uzmanlardan edinilen bilgilerin kesin olduğuna inandıklarının göstergesidir. Öğretmenlerin bu şekilde düşünmeleri onların bilginin tek ve kesinliği konusunda hala geleneksel kalıplarda olduğunu göstermektedir. Bu, yapılandırmacı yaklaşımın gerekliliklerinden olan bilgiyi keşfetme sonucu ortaya çıkacak çıktıları kabul etmeyecek bir inançtır. Dolayısıyla bu sonuç öğretmenler açısından pek olumlu bir sonuç değildir.

Araştırma bulgularına göre epistemolojik inanç ölçeğindeki, bilginin kaynağı uzmandır ve ögrenme yetenek işidir alt boyutunda cinsiyet değişkeni açısından anlamlı bir farklılık ortaya çıkmadığı görülmüştür (Tablo 5). Alan yazın incelendiğinde cinsiyet değişkeni ile ilgili bulgular bazı çalışmalarla paralellik göstermektedir. Karhan (2007)'ın çalışmasında, epistemolojik inanç ölçeği ve alt boyutları bazında yapılan karşılaştırmada erkek ve kadın öğretmenler arasında anlamlı düzeyde fark bulunamamıştır. Izgar ve Dilmaç (2009) tarafından yönetici adayı öğretmenler üzerinde yapılan araştırma sonucunda da kadın ve erkek öğretmenlerin epistemolojik inançlarının anlamlı düzeyde farklılaşmadığ1 sonucuna ulaşılmıştır. İçen (2012) araştırmaya katılan ilköğretim okullarında görev yapan sosyal bilgiler öğretmenlerinin "Bilginin kaynağı uzmandır ve öğrenme yetenek işidir" inanç puanı ortalamalarının cinsiyet değişkenine göre anlamlı bir farklılık olmadığg sonucunu bulmuştur. 
Diğer taraftan bu bulguyla farklılık gösteren çalışmalarda literatürde yer almaktadır. Bacanlı-Kurt (2010), cinsiyet değişkenini "bilginin kaynağı uzmandır ve öğrenme yetenek işidir” boyutunda öğretmenlerin görüşlerini farklılaştıran bir değişken olarak görmektedir. Kadın öğretmenlerin erkek öğretmenlere göre bu alt boyutta daha gelişmiş epistemolojik inançlara sahip olduğunu belirtmiştir. Ölçek alt boyutları, öğrenme çabaya bağlı değildir ve bilgi tek ve kesindir alt boyutlarında cinsiyet değişkenine göre kadın öğretmenler lehine anlamlı sonuçlar bulunmuştur. Bu bulgular epistemolojik inançları üzerinde yapılan diğer araştırma sonuçlarıyla da büyük ölçüde tutarlılık göstermektedir (Deryakulu, ve Bıkmaz, 2003; Öngen, 2003; Deryakulu ve Büyüköztürk, 2005; Taşkın, 2013).

Alan yazında epistemolojik inançların cinsiyete göre değiştiğini gösteren araştırma bulgularına ulaşılmıştır. Hofer (2000), kadın üniversite öğrencilerinin, erkek öğrencilere oranla bilgiyi daha az kesin olarak gördükleri ve bilginin edinilmesinde daha az otoriteye bağlı kaldıklarını, Deryakulu ve Büyüköztürk (2005) tarafından yapılan çalışmada kadın öğrencilerin erkek öğrencilerden daha gelişmiş/olgunlaşmış epistemolojik inançlara sahip olduğunu göstermiştir. Eroğlu ve Güven (2006), üniversite öğrencilerinin epistemolojik inançlarını inceledikleri araştırmalarında, kadın öğrencilerin erkek öğrencilere kıyasla epistemolojik inançlarının öğrenmenin çabaya bağlı olduğu boyutundaki inancı daha çok benimsediklerini ortaya çıkarmıştır. Schommer (2003), cinsiyet ile epistemolojik inançlar arasındaki ilişkiyi incelediği araştırmasında, kadın öğrencilerin erkek öğrencilere kıyasla öğrenmenin hemen gerçekleştiğine daha az inandıkları sonucuna ulaşmıştır. Oğuz (2008), Türk üniversite öğrencileri üzerinde yaptı̆̆ 1 araştırmada kadın öğrencilerin öğrenmenin yeteneğe oranla çabayla daha fazla ilişkili olduğuna erkeklerden daha güçlü bir biçimde inandıklarını belirlemiştir (aktaran Aypay, 2011, s. 12). Chai, Khine ve Teo (2006), epistemolojik inançların cinsiyetle ilişkisinde kadın öğrencilerin lehine sonuçlara ulaşmıştır. Akyıldız (2014), lise öğretmenlerinin öğrenme çabaya bağlı değildir alt boyutunda kadın öğretmenlerin epistemolojik inançların erkek öğretmenlere göre daha olgunlaşmış olduğunu söylemiştir.

Araştırmada, öğretmenlerin epistemolojik inançların “öğrenme çabaya bağlı değildir” ve "bilgi tek ve kesindir" boyutlarında cinsiyet değişkenine göre, kadın öğretmenlerle erkek öğretmenler arasında kadın öğretmenlerin lehine anlamlı bir fark ortaya çıkmışken "bilginin kaynağı uzmandır ve öğrenme yetenek işidir " boyutunda anlamlı bir farklılık ortaya çıkmamıştır. Kadın öğretmenlerin erkek öğretmenlere göre, bilginin herkes tarafından üretilebileceğine ve öğrenmenin bir yetenek işi olmadığına, çabayla zamanla geliştirilebileceğine daha çok inanmaktadırlar.

Fen bilgisi öğretmenlerinin epistemolojik inanç ölçeğine yönelik görüşleri mesleki deneyim yıllarına göre farklılaştı̆ğ görülmektedir (Tablo 6-7). Ölçeğin 3 alt boyutunda anlamlı farklılıklar olduğu belirlenmiştir. Bilginin kaynağı uzmandır ve öğrenme yetenek işidir alt boyutunda mesleki kıdem açısından 1-5 yıllık deneyime sahip öğretmenlerin diğer kıdemdeki öğretmenlere göre daha gelişmiş bir epistemolojik inanca sahip oldukları görülmektedir. 1-5 yıllık öğretmenler bilginin kendileri tarafindan üretilebileceğine ve öğrenmenin sonradan gelişebileceğine olan inanca daha yakın oldukları görülmüştür. Kıdem süresi arttıkça bilginin kaynağının uzman olmadığı ve öğrenmenin yetenek 
olmayacağına ilişkin düşüncelerin oluştuğu söylenebilir. Kıdem süresi 1-5 yıl olan öğretmenler ile daha fazla kıdeme sahip olan öğretmenler arasında 1-5 yıl lehine farklılıklar bulunmuştur. Göreve yeni başlayan ya da uzmanlaşma yolunda olan öğretmenler daha fazla çalışan emeklilik yolunda olan öğretmenlere göre daha sofistike epistemolojik inanç taşıdıkları şeklinde yorumlanabilir. Meslekteki deneyimi daha fazla olan öğretmenler, mesleğe yeni başlayan ve uzmanlaşmaya giden öğretmenlerden çok daha fazla tek ve değişmez doğrular olduğu inancını taşımaktadırlar. Bu bulgu, genç öğretmenlerin yaşlı ögretmenlere göre daha sofistike epistemolojik inançlar taşıdıkları şeklinde yorumlanabilir. $\mathrm{Bu}$ sonuç yeni mezun fen bilgisi öğretmenlerinin pedagojik açıdan daha zengin olan eğitim fakültelerinden mezun olması olarak da değerlendirilebilir. Epistemolojik inanç ölçeğinin bütününe ilişkin kıdemler aras1 fark incelendiğinde ise, 1-5 y1l ve 6-10 yıl deneyime sahip öğretmenlerin daha deneyimli öğretmenlere göre daha sofistike inançlara sahip olduğu görülmüştür.

Alan yazında yer alan araştırmalarda da benzer yönde bulgulara ulaşılmıştır. Bunlardan, Karhan (2007) yaptığı araştırmada, alt boyutlar bazında bakıldığında öğrenmenin yetenek işi ve bilginin kaynağına ilişkin inanç olan birinci boyut ile çabanın sonuç vereceğine olan inanç boyutunda kıdemler arası anlamlı fark görülmezken, bilginin tek ve kesin doğru olduğuna inanç boyutunda anlamlı düzeyde fark elde edilmiştir. Bacanl1-Kurt (2010) yaptığı araştırmada, öğretmenlerin epistemolojik inançlarının "bilginin kaynağı uzmandır ve öğrenme yetenek işidir” ve "öğrenme çabaya bağlı değildir” boyutlarında kıdem değişkenine göre anlamlı düzeyde farklılaştı̆̆ı, "bilgi tek ve kesindir" boyutunda ise kıdem değişkenine göre anlamlı farklılık olmadığı yönünde sonuca ulaşmıştır. Bacanlı Kurt'un ve bizim araştırmamızda, "bilginin kaynağı uzmandır ve öğrenme yetenek işidir" alt boyutunda, kıdeme ilişkin anlamlı düzeyde fark olduğu bulunmuşken. Karhan'ın (2007)araştırmasında kıdeme ilişkin anlamlı düzeyde fark olmadığı belirlenmiştir. "Öğrenme çabaya bağlı değildir” alt boyutunda kıdeme ilişkin hem Bacanl1-Kurt'un araştırmasında, hem de bizim araştırmamızda anlamlı düzeyde fark bulunmuştur. "Bilgi tek ve kesindir" alt boyutuna ilişkin ise kıdem değişkenine göre Bacanlı Kurt tarafindan anlamlı düzeyde fark bulunamazken; hem bizim araştırmamızda, hem de Karhan'ın araştırmasında anlamlı düzeyde fark elde edilmiştir. İçen (2012) araştırmasında, "bilginin kaynağı uzmandır ve öğrenme yetenek işidir" alt boyutunda mesleki kıdem değişkenine göre anlamlı düzeyde fark bulunamamıştır. Ancak "öğrenme çabaya bağlı değildir” ve "bilgi tek ve kesindir" alt boyutları ile ve tüm ölçek bazında mesleki kıdem değişkenine göre anlamlı düzeyde fark bulunmuştur. Bulgulara göre, 1-10 yıl kıdeme sahip öğretmenlerin, 21 yıl ve üstü kıdeme sahip öğretmenlere göre daha sofistike epistemolojik inançlara sahip oldukları görülmüştür. Akyıldız (2014) araştırmasında, katılımcı öğretmenlerinin epistemolojik inançlarının "bilginin kaynă̆ uzmandır ve öğrenme yetenek işidir" alt boyutuna ilişkin görüşleri arasında kıdem değişkenine göre anlamlı bir farklılık ortaya çıkmamıştır. Ancak, öğretmenlerin, "öğrenme çabaya bağlı değildir" ve "bilgi tek ve kesindir" boyutu ile ilgili inançları arasında ise kıdem değişkenine göre anlamlı düzeyde bir farklılık olduğu yönünde bulgulara ulaşılmıştır. Bu bulgu, öğretmenlerin, "öğrenme çabaya bağlı değildir” ve "bilgi tek ve kesindir" boyutlarında alt kıdemlerde gelişmiş (sofistike) olan inançlarının kıdemleri arttıkça gelişmemiş (naif) inançlara doğru 
değiştiğini göstermektedir. 1-5 kıdemdeki öğretmenlerin daha yüksek kıdemdeki öğretmenlere göre, daha gelişmiş epistemolojik inançlara sahip olmalarının bu durumdan kaynaklandığı söylenebilir. Buradan hareketle, öğretmenlerin mesleki kıdemleri arttıkça önceki inançlarını daha çok sahiplendikleri, değişime açık olmadıkları ve eğitimde yapılan değişiklikleri kolayca benimsemedikleri çıkarımında bulunulabilir. Ayrıca, uzun mesleki yaşamlarında yerleşik uygulamalar sonucunda oluşan deneyimlerinin inançların gelişimine engel oluşturduğu sonucuna varılabilir.

Fen bilgisi öğretmenlerinin mezun oldukları kurum değişkenine yönelik epistemolojik inanç alt boyutları açısından sadece öğrenme çabaya bağlı değildir alt boyutunda farklılaşma görülmezken diğer alt ölçek boyutlarında farklılaşma olduğu görülmektedir. "Bilginin kaynağı uzmandır ve öğrenme yetenek işidir” boyutunda mezun olunan kuruma göre eğitim fakültesi ve diğer fakülte mezunu öğretmenler ile eğitim enstitüsü mezunu öğretmenler arasında anlamlı farklılık bulunmuştur. Fakülte mezunu öğretmenler eğitim enstitüsü mezunu öğretmenlere göre daha gelişmiş epistemolojik inançlara sahip oldukları görülmüştür. Araştırmada epistemolojik inançların "bilgi tek ve kesindir" boyutunda mezun olunan kuruma göre eğitim fakültesi mezunu öğretmenler ile eğitim enstitüsü ve diğer fakülte mezunu öğretmen görüşleri arasında anlamlı düzeyde farklılaşma görülmüştür. Eğitim fakültesi mezunu öğretmenlerin eğitim enstitüsü ve diğer fakülte mezunu olan öğretmenlere göre daha gelişmiş epistemolojik inançlara sahip olmaları, eğitim fakültesinde verilen ders içerikleri ile ilgili olabileceğinden kaynaklı olabilir. Epistemolojik inanç ölçeği geneline bakıldığı zaman, eğitim fakültesi ve diğer fakültelerden mezun fen bilgisi öğretmenlerinin epistemolojik inançları ile bu fakülteler dışından mezun olunan kurumlardaki öğretmenler arasında anlamlı farklılıklar olduğu görülmüştür. Alan yazındaki araştırmalarda benzer yönde bulgulara ulaşılmıştır. İçen (2012), eğitim fakültesi mezunu olan sosyal bilgiler öğretmenlerinin epistemolojik inançlarının, eğitim fakültesi mezunu olmayanlara göre daha sofistike olduğu şeklinde belirtmiştir. Buna göre üniversite eğitiminin ve eğitim fakültesi mezuniyetinin epistemolojik inançların gelişmesinde pozitif katkı yaptığını söylemek mümkündür. Araştırmamızın bulguları Karhan (2007)'ın yaptığı araştırmanın bulgularıyla da benzerdir. Karhan (2007), eğitim fakültesi dışındaki öğretmen yetiştiren kurumlardan mezun olan öğretmenlerin ortalamaları diğer iki gruptan daha yüksektir. Dolayısıyla bu eğitim kurumlarından mezun öğretmenler bilginin tek ve kesin olduğuna daha çok inanmaktadırlar sonucuna ulaşmıştır. Akyıldız (2014), araştırmasında epistemolojik inançların "bilginin kaynağı uzmandır ve öğrenme yetenek işidir", “öğrenme çabaya bağlı değildir” ve "bilgi tek ve kesindir" boyutlarında lisans mezunu öğretmenlerle lisansüstü mezunu olan öğretmenlerin görüşleri, lisansüstü öğretmenlerin lehine, anlamlı düzeyde farklılaştığı sonucuna ulaşmıştır.

Eğitim enstitüsü ile 4 yıllık fakülte mezunu olan öğretmenler arasında farklar çıkmıştır ki, bu öğretmenler aynı zamanda kıdem olarak uzun süredir meslekte olan öğretmenlerdir. Bu bulgu, fakülte mezunu olmayan, emekliliğe yaklaşmış öğretmenlerin epistemolojik inançlarının fakülte mezunu olan öğretmenlere oranla daha az sofistike olduğunu düşündürmektedir. Araştırma bulgularından yola çıkarak üniversite eğitimin ve üniversitede alınan farklı bölümlerdeki eğitimin niteliği ve içeriğiyle 
bağlantılı olabileceği sonucuna varabiliriz. Milli Eğitim Bakanlığı’nın son yıllardaki yapılandırmacı eğitim yeniliğinin başarıya ulaşabilmesi için ortaokullarda görev yapan her branştaki öğretmenin gelişmiş epistemolojik inançlara sahip olması için daha fazla çaba harcanmalıdır. Eğitim Bakanlığı'nın ortaokullarda görev yapan öğretmenlerin epistemolojik inançlarını geliştirmeye yönelik girişimleri, üniversitelerle koordineli bir biçimde yapmalıdır. Bu girişimler, ortaklaşa düzenlenecek olan seminer ve konferanslar şeklinde olabilir. Milli Eğitim Bakanlığı tarafından, epistemolojik olarak gelişmiş epistemolojik anlayışa dayalı olarak geliştirilen öğretim programlarının, sınıflarda doğasına uygun olarak uygulanabilmesi için bu öğretmenleri yetiştiren Eğitim Fakültesi öğretim programlarına epistemolojik tabanlı dersler eklenmelidir. Eğitim fakültesi dışındaki fakültelerden mezun olanların da formasyon eğitimi alarak atandığı göz önünde bulundurulursa, aynı derslerin bu öğrencilere yönelik pedagojik formasyon eğitiminde de yer alması yararlı olacağı düşünülmektedir. Fen bilgisi ögretmenlerine yönelik verilecek bir hizmet içi eğitimle epistemolojik inançları geliştirilebilir. Böylece, ögretmenlerin sınıf içi eğitim uygulamalarında daha yapılandırmacı bir anlayışı benimsemeleri sağlanabilir.

\section{KAYNAKÇA}

Aksan, N. \& Sözer M. A. (2007). Üniversite öğrencilerin epistemolojik inançları ile problem çözme becerileri arasındaki ilişkiler. Ahi Evren Üniversitesi Kırşehir Eğitim Fakültesi Dergisi (KEFAD) Cilt 8, Sayı 1, 31-50.

Akyıldız, S. (2014). Lise öğretmenlerinin epistemolojik inançları ile öğretme-öğrenme anlayışları arasındaki ilişkinin incelenmesi. Yayınlanmamış Doktora Tezi, Fırat Üniversitesi, Eğitim Bilimleri Enstitüsü, Elazığ.

Arredondo, D.E. \& Terrance, T.R. (1996). Epistemological beliefs of Chilean educators and school reform efforts. Paper presented at the Tercer Encuentro National de Enfoques Actuales en education Pontificia Universidad Catohea Chile Santiago de Chile. ED 402673.

Aypay, A. (2011). Epistemolojik inançlar ölçeğinin Türkiye uyarlaması ve öğretmen adaylarının epistemolojik inançlarının incelenmesi. Osmangazi Üniversitesi Sosyal Bilimler Dergisi, 12(1), 1-15.

Bacanl1- Kurt, C. (2010). Öğretmenlerin epistemolojik inançlart ve değişime direnme tutumları arasındaki ilişkilerin incelenmesi. Yayınlanmamış Yüksek Lisans Tezi, Gazi Üniversitesi, Eğitim Bilimleri Enstitüsü, Ankara.

Baç, M. (2011). Epistemoloji. Anadolu Üniversitesi Yayınları.

Beck, J., Czerniak, C. \& Lumpe, A. (2000). An exploratory study of teachers' beliefs regarding to implementation of constructivism in their classroom. Journal of Science Teacher Education, 11, 323 343. 
Brown, C. A. \& Cooney, T. J. (1982). Research on teacher education: a philosophical orientation. Journal of Research and Development in Education, 15: 13-18.

Buehl, M. M. \& Alexander, P. A. (2001). Beliefs about academic knowledge. Educational Psychology Review, 13(4), 385-418.

Buehl, M. M. (2008). Assessing the multidimensionality of students' epistemic beliefs across diverse cultures. In Knowing, Knowledge And Beliefs (pp. 65-112). Springer Netherlands.

Chai, C. S., Khine, M. S. \& Teo, T. (2006). Epistemological beliefs on teaching and learning: a survey among pre-service teachers in Singapore. Educational Media International, 43(4), 285298.

Chan, K.-W. \& Elliott, R. G. (2000). Exploratory study of epistemological beliefs of Hong Kong teacher education students: Resolving conceptual and empirical issues. Asia-Pacific Journal of Teacher Education, 28(3), 225-234.

Chan, K. \& Elliott, R. G. (2004). Epistemological beliefs across cultures: critique and analysis of beliefs structure studies. Educational Psychology,(24) 2, 133-140.

Chan, K. (2008). Epistemological beliefs, learning, and teaching: The Hong Kong cultural context. Knowing, Knowledge and Beliefs: Epistemological Studies across Diverse Cultures. M. S. Khine (ed.), Springer Science + Business Media B.V. e-ISBN 978-1-4020-6596-5.

Deryakulu, D. (2004). Üniversite öğrencilerinin öğrenme ve ders çalışma stratejileri ile epistemolojik inançları arasındaki ilişki. Kuram ve Uygulamada Eğitim Yönetimi, 38: 230-249.

Deryakulu, D. (2004a). Epistemolojik inançlar. Kuzgun, Y. ve Deryakulu, D. (ed.). Eğitimde bireysel farklılıklar (s. 259-289). Ankara: Nobel Yayın Dağıtım.

Deryakulu, D. \& Büyüköztürk, Ş. (2005). Epistemolojik inanç ölçeğinin faktör yapısının yeniden incelenmesi: Cinsiyet ve öğrenim görülen program türüne göre epistemolojik inançların karşılaştırılması. Eğitim Araştırmaları, Vol: 18, ss. 57-70.

Deryakulu, D. \& Bıkmaz, H. F. (2003). Bilimsel epistemolojik inançlar ölçeğinin geçerlik ve güvenirlik çalışması. Eğitim Bilimleri ve Uygulama, 4, 243-257.

Duell, O. K. \& Schommer-Aikins, M. (2001). Measures of people's beliefs about knowledge and learning. Educational Psychology Review, 13(4), 419-449.

Ekiz, D. (2006). Öğretmen eğitimi ve öğretimde yaklaşımlar. Ankara, Nobel Yayınları.

Ekonomik İşbirliği ve Kalkınma Örgütü (OECD). (2009). Teaching practices, teachers ' beliefs and attitudes. Creating Effective Teaching and Learning Environments: First Results from TALIS.

Erdem, M. Yılmaz, A. \& Akkoyunlu, B. (2008). Öğretmen adaylarının bilgi okuryazarlık özyeterlik inançları ve epistemolojik inançları üzerine bir çalışma. International Educational Technology Conference (IECT), Anadolu Üniversitesi, Eskişehir. 
Eroğlu, S. E. \& Güven, K. (2006). Üniversite öğrencilerinin epistemolojik inançlarının bazı değişkenler açısından incelenmesi. Selçuk Üniversitesi Sosyal Bilimler Enstitüsü Dergisi, 16, 295-312.

Fer, S. (2011). Öğretim tasarımı. Ankara, Anı Yayıncılık.

Fullan, M. (2001). The New Meaning of Educational Change. Routledge: London Cassel Educational Limited.

Hashweh, M. Z. (1996). Effects of science teachers' epistemological beliefs in teaching. Journal of Research in Science teaching, 33(1), 47-63.

Hofer, B. K. (2000). Dimensionality and disciplinary differences in personal epistemology. Contemporary Educational Psychology, 25(4), 378-405.

Hofer, B. K. (2008). Personal Epistemology and Culture. Knowing, Knowledge and Beliefs: Epistemological Studies across Diverse Cultures. M. S. Khine (ed.), (pp. 3-22). Springer Netherlands.

Hofer, B. K. \& Pintrich, P. R. (1997). The development of epistemological theories: Beliefs about knowledge and knowing and their relation to learning. Review of Educational Research, 67: 88140.

Izgar, H. \& Dilmaç, B. (2009). Yönetici adayı öğretmenlerin özyeterlik algıları ve epistemolojik inançlarının incelenmesi. http://www.sosyalbil.selcuk.edu.tr/sos_mak/ articles/2008/20/HIZGARBDILMAC.PDF adresinden 24.07.2009 tarihinden alınd1.

İçen, M. (2012). Sosyal bilgiler öğretmenlerinin epistemolojik inançlarının sınıf içi uyguladıkları ögretim stratejileri ile ilişskisi. Yayımlanmamış Yüksek Lisans Tezi, Erzincan Üniversitesi Sosyal Bilimler Enstitüsü İlköğretim Anabilim Dalı, Soysal Bilgiler Eğitimi Bilim Dalı, Erzincan.

Kaleci, F. \& Yazıc1, E. (2012). Epistemolojik inançlar üzerine bir derleme. X. Ulusal Fen Bilimleri ve Matematik Eğitim Kongresi. 27-30 Haziran 2009, Niğde Üniversitesi Eğitim Fakültesi. Niğde.

Karasar, N. (2012). Bilimsel araştırma yöntemi. (23.Basım). Ankara: Nobel.

Karhan, İ. (2007). İlköğretim okullarında görev yapan öğretmenlerin epistemolojik inançlarının demografik özelliklerine ve bilgi teknolojilerini kullanma durumlarına göre incelenmesi. Yayımlanmamış Doktora Tezi, Yıldız Teknik Üniversitesi, Sosyal Bilimler Enstitüsü. İstanbul.

Kıralp, A. Y., Şahin, F. S. \& Dinçyürek, S. (2008). Denetim odağı farklı psikolojik danışmanlık ve rehberlik (pdr) öğrencilerinin epistemolojik inançları. Dokuz Eylül Üniversitesi Buca Eğitim Fakültesi Dergisi, 23, 98-106.

K1ssack, M. (2002). Hermeneutik ve eğitim: İnsan bilimleri öğretmenleri için düşünceler, (Çev. Vefa Taşdelen). Ankara Üniversitesi Eğitim Bilimleri Fakültesi Dergisi. Cilt: 35, sayı: 1-2.

Neuman, W. L. (2008). Toplumsal araştırma yöntemleri (3. Baskı). (S.Özge, Çev.). İstanbul: Yayınodası Yayınc1lı. 
Öngen, D. (2003). Epistemolojik inançlar ile problem çözme stratejileri arasındaki ilişkiler: Eğitim fakültesi öğrencileri üzerine bir çalışma. Ĕ̆itim Araştırmaları Dergisi, Sayı:13, s. 155-162.

Özbaş, N. (2013). Sinıf ögretmenlerinin düşünme stillerinin kullandıkları yöntemler ve epistemolojik inançları açısından incelenmesi. Yayınlanmamış Yüksek Lisans Tezi, Amasya Üniversitesi, Sosyal Bilimler Enstitüsü, Amasya.

Özdemir, İ. (2013). İlköğretim ikinci kademe öğretmenlerinin epistemolojik inançları ile yapılandırmacı yaklaşıma yönelik tutumları arasındaki ilişki. Yayınlanmamış Yüksek Lisans Tezi, Pamukkale Üniversitesi, Eğitim Bilimleri Enstitüsü, Denizli.

Paul, R. \& Elder, L. (2002). Critical thinking: Tools for taking charge of your professional and personal life. FT Press.

Savaşç1-Açıkalın, F. (2009). Teacher beliefs and practice in science education. In Asia-Pacific Forum on Science Learning and Teaching (Vol. 10, No. 1, pp. 1-14). Hong Kong Institute of Education. 10 Lo Ping Road, Tai Po, New Territories, Hong Kong.

Schommer, M. (1990). Effects of beliefs about the nature of knowledge on comprehension. $J$. Educ. Psychol. 82: 498-504.

Schommer, M. (1993). Epistemological development and academic performance among secondary students. Journal of Educational Psychology. c. 85. s. 3: 406-411.

Schommer, M. (1998). The influence of age and schooling on epistemological beliefs. The British Journal of Educational Psychology. s. 68: 551-562.

Schommer, M. \& Walker, K. (1997). Epistemological beliefs and valuing school: Considerations for college admissions and retendion. Researc in Higher Education, Vol, 38, No. 2.

Schommer, M. \& Dunnell, P. A. (1997). Epistemological beliefs of gifted high school students. Roeper Review, 19(3), 153-156.

Schommer-Aikins, M. (2002). An evolving theoretical framework for an epistemological belief system. In B. K. Hofer and P. R. Pintrich (Eds) Personal Epistemology: The Psychology of Beliefs about Knowledge and Knowing. New Jersey: Erlbaum

Tanriverdi, B. (2012). Pre-service teachers' epistemological beliefs and approaches to learning. Procedia-Social and Behavioral Sciences, 46, 2635-2642.

Taşkın, Ç. Ş. (2013). Epistemolojik inançlar: Öğretmen adaylarının öğrenme yaklaşımlarını yordayıcı bir değişken/Epistemological beliefs: As predictors of preservice teachers' learning approaches. Mustafa Kemal Üniversitesi Sosyal Bilimler Enstitüsü Dergisi, 9(19).

Tezci, E. \& Uysal, A. (2004). Eğitim teknolojisinin gelişimine epistemolojik yaklaşımların etkisi. The Turkish Online Journal of Educational Technology TOJET, 3 (2), 158- 164. 


\section{Extended Abstract}

Epistemological belief focuses on beliefs about what an individual's knowledge is, how it is learned, and how learning takes place It also includes how to acquire knowledge, what is the degree of certainty of knowledge, what are the limits of information. Individuals who have developed their epistemological beliefs know that knowledge has a complex structure, learning capacity can be developed and an effort should be done to realize effective learning. Epistemological beliefs are important cognitive variables which affect learning-teaching processes and they directly affect students' academic achievement. Researches have shown that teachers' values and beliefs towards teaching and learning affect their classroom activities. Researches have also proved that epistemological beliefs have great effect on learning. In this study, epistemological beliefs of science teachers were investigated in terms of gender, teaching experience and type of institution graduated from. Survey method was used in the study and totally 200 science teachers working in Elazı̆g city and provinces were included in the study. Of the 200 science teachers, 95 are female and 105 are male. Data were obtained by using "Epistemological Beliefs Scale" developed by Schommer (1998) and adapted into Turkish by Karhan (2007). The scale is a five-point Likert style scale. The items are ranged from "strongly disagree" to "totally agree". The scale includes three subscales. Cronbach alpha reliability coefficient of the overall scale was measured to be .84 . Cronbach Alpha reliability coefficients of the subscales were measured to be $.79, .81$ and .76 respectively. The obtained data were analyzed using SPSS packet program. Independent groups t test, One Way ANOVA, Levene test, Mann Whitney U and Kruskal Wallis H tests were used to analyze the data. LSD Test was used in order to find out differences occurred between which groups. Study results revealed significant differences among Science teachers in terms of several variables. Prior to Independent groups $t$ test and One Way ANOVA, the homogeneity of the variances was tested through the Levene Test. In a prior examination, when the distribution of the data was found to be non-normal, the non-parametric statistical technique Mann-Whitney $U$ was used instead of Independent groups t test and Kruskal Wallis H test was used instead of One Way Anova. When the distribution of the data was found normal, the parametric statistical technique, the independent groups t-test and One Way Anova were was used to analyze the data. Results with $\mathrm{p}<0.05$ were considered statistically significant.

It was found that science teachers have developed epistemological beliefs in "expert is a source of knowledge and learning is a talent" dimension of epistemological beliefs; have weak beliefs in "learning does not depend on effort" dimension; and they have traditional beliefs in "knowledge is unique and certain" dimension of epistemological beliefs. Study results revealed significant differences among Science teachers in terms of several variables. In the study, in some dimensions of epistemological beliefs resulted in favor of female teachers on the basis of gender variable. Except for first factor, statistically significant differences were found on behalf of female. According to teaching experience, significant differences were found on behalf of less experienced ones. It is also found that except for second factor some significant differences were observed according to the institution graduated from. These important differences are generally on behalf of education faculty and other faculties. Based on the study results, some implications and recommendations are offered. As a result of the study it is suggested that Ministry of National Education should spend efforts to help each of middle school teachers to have developed epistemological beliefs and through co-operating with universities seminars and conferences should be arranged for teachers. It is also suggested that epistemological based courses should be added to programs, through in-service training course teachers' epistemological beliefs should be improved, on epistemological beliefs should be carried out at education faculties. 